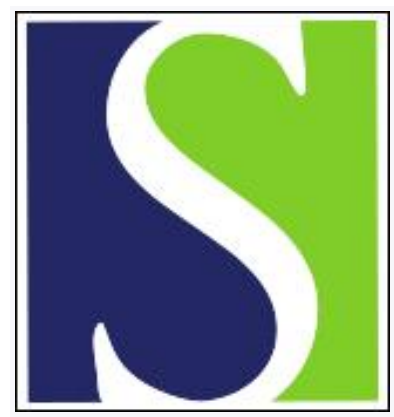

Scand J Work Environ Health 2004;30(4):261-278

https://doi.org/10.5271/sjweh.794

Issue date: Aug 2004

Gender differences in the relations between work-related physical and psychosocial risk factors and musculoskeletal complaints

by Hooftman WE, van Poppel MNM, van der Beek AJ, Bongers PM, van Mechelen W

Affiliation: Department of Public and Occupational health, Institute for Research in Extramural Medicine, Van de Boechorstraat 7, NL-1081 BT Amsterdam, The Netherlands. w.hooftman@vumc.nl

Refers to the following texts of the Journal: 1999;25(5):410-414 2002;28(1):25-32 2001;27(1):49-56 1997;23(2):121-129 1997;23(4):243-256 2001;27 suppl 1:1-102 1999;25(3):163-185 $1996 ; 22(3): 165-175 \quad 1999 ; 25(5): 387-403 \quad 2000 ; 26(1): 7-19$ $1997 ; 23(3): 179-186 \quad 1999 ; 25(3): 246-254$

The following articles refer to this text: 2004;30(4):257-259; 2009;35(2):85-95; 2016;42(2):125-134

Key terms: back; gender; gender difference; literature study; lower extremity; musculoskeletal complaint; neck; occupational risk factor; physical load; physical risk factor; psychosocial load; psychosocial risk factor; review; sex factor; systematic review; upper extremity; work

This article in PubMed: www.ncbi.nlm.nih.gov/pubmed/15458009

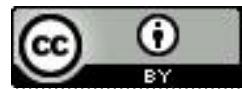




\title{
Gender differences in the relations between work-related physical and psychosocial risk factors and musculoskeletal complaints
}

\author{
by Wendela E Hooftman, MSc, ${ }^{1,2}$ Mireille NM van Poppel, PhD, ${ }^{1,2}$ Allard J van der Beek, PhD, ${ }^{1,2}$ Paulien M \\ Bongers, PhD, ${ }^{2,3}$ Willem van Mechelen, $P h D^{1,2}$
}

\begin{abstract}
Hooftman WE, van Poppel MNM, van der Beek AJ, Bongers PM, van Mechelen W. Gender differences in the relations between work-related physical and psychosocial risk factors and musculoskeletal complaints. Scand $J$ Work Environ Health 2004;30(4):261-278.

Gender differences in the prevalence of musculoskeletal complaints might be explained by differences in the effect of exposure to work-related physical and psychosocial risk factors. A systematic review was conducted to examine gender differences in the relations between these risk factors and musculoskeletal complaints. Several electronic databases were searched. The strength of the evidence was determined on the basis of the methodological quality and consistency of the study results. For lifting, strong evidence was found that men have a higher risk of back complaints than women. The same was found for the relation between hand-arm vibration and neckshoulder complaints. For arm posture, strong evidence was found that women have a higher risk of neckshoulder complaints than men. For social support, no evidence of a gender difference was found for either neckshoulder or back complaints. For hand-wrist and lower-extremity complaints, inconclusive evidence was found due to a lack of high-quality studies.
\end{abstract}

Key terms back, literature study, lower extremities, neck, occupational, physical load, psychosocial load, sex factors, systematic review, upper extremities.

Many studies have reported gender differences in the prevalence of musculoskeletal complaints. For example, in a large population-based study in The Netherlands, $79.3 \%$ of the women and $71.5 \%$ of the men reported one or more musculoskeletal complaints in the past year (1). The one-year prevalence of self-reported spinal pain (including lower back, upper back, and neck) in a sample of 35- to 45-year-old Swedish residents was $69.5 \%$ for women and $63.2 \%$ for men (2). In the United States the prevalence of chronic joint symptoms in 2001 was $37.3 \%$ for women and $28.4 \%$ for men (3).

This gender difference seems to be more distinct for neck and upper-extremity complaints than for back complaints. The prevalences of neck and upper-extremity complaints has been found to be consistently higher for women than for men $(1,4,5)$, while the prevalence of back complaints has been shown to be markedly higher for women (6) or slightly higher for women $(1,4)$ and also slightly higher for men (7).
Several explanations have been proposed for the gender difference in prevalence (8-11). First, it has been proposed that men and women have different exposure to risk factors, either because of differences in exposures outside work or because of differences in work exposure due to the sex segregation of the labor market. This last factor has been suggested to be the most important explanation for the sex difference in the prevalence of musculoskeletal complaints. However, the difference in prevalence remains when men and women from the same occupational class (12), or with the same work tasks (13) are compared. Second, it is claimed that women are more prone to express pain and symptoms, either because they have a lower threshold for detecting pain and symptoms or because they are more willing to express their feelings than men, who are taught not to complain (14). If this were true, one would expect that the gender difference in the prevalence of self-reported pain or symptoms would be larger than for objectively

1 Department of Public and Occupational Health, Institute for Research in Extramural Medicine, VU University Medical Center, Amsterdam, The Netherlands.

2 Body@Work, Research Center Physical Activity, Work and Health, TNO VUmc (Netherlands' Organisation for Applied Scientific Research, VU University Medical Center), The Netherlands.

3 TNO Work and Employment, Hoofddorp, The Netherlands.

Correspondence to: Dr Allard van der Beek, Department of Public and Occupational Health, Institute for Research in Extramural Medicine, Van de Boechorststraat 7, NL-1081 BT Amsterdam, The Netherlands. [E-mail: a.vanderbeek@vumc.nl] 
measured problems. Yet, Punnett \& Herbert (8), who reported that some of the largest gender differences were found in studies in which objective measures were used, did not show this result. The third explanation to be suggested is that the same risk factors may have a different effect on men and women. In this respect, it has been pointed out that joint laxity seems to be influenced by sex hormones $(15,16)$, women therefore being more vulnerable for musculoskeletal pain. In addition, women, on the average, have smaller body dimensions, lower muscle force, and a lower aerobic capacity. Therefore tasks performed with the same (absolute) exposure will, in most cases, result in a higher relative workload for women $(8,17,18)$, which could lead to more complaints. Finally, men and women have been found to use different coping strategies for dealing with occupational stressors (19), and this difference could result in different outcomes.

In this review we focus on gender differences in the effect of risk factors. The aim was to determine whether there are gender differences in the relations between work-related physical and psychosocial risk factors and musculoskeletal complaints of the back, neck-shoulder, hand-wrist, and lower extremities.

\section{Methods}

\section{Selction of the literature}

Several electronic databases, MEDLINE (1966-December 2002), CINAHL (1982-December 2002), Psychinfo (1887-December 2002), CisDoc, NIOSHtic2, HSEline, RILOSH (1977-February 2002), and Biological Abstracts (1990-January 2002), were checked in order to identify relevant studies. The databases were searched with the following search string: (risk factor OR predictor OR determinant or causality OR (a)etiology OR causal factor) AND (gender (difference) OR sex (difference)) AND (work(-)(related) OR work environment OR job OR employment OR workplace OR occupation(al)) AND (back (pain) OR musculoskeletal (disorder) OR upper extremity (disorder) OR lower extremity (disorder) OR shoulder OR wrist OR elbow OR neck OR knee OR RSI OR repetitive strain injury OR cumulative strain disorder OR hand OR arm OR leg OR foot OR feet). In addition, a snowball search was performed, and the references of some recent reviews (2025) were checked for relevant publications. Finally, articles from personal databases were included.

Articles were included if they met the following criteria: (i) the study design was cohort, case-control or cross-sectional, (ii) the study population included both men and women who came from a working or community-based population, (iii) the study addressed a musculoskeletal complaint, (iv) the exposure to relevant risk factors was measured separately for men and women and, for example, not based on job title or a job exposure matrix, (v) separate analyses were performed for men and women or an interaction effect for gender was calculated, and (vi) the study was published in a peerreviewed journal in English. Two reviewers (WH and MP) read the titles and abstracts of all the studies to decide whether the inclusion criteria were met. If no abstract was present or if, based on title and abstract, it still was unclear whether an article should be included or excluded, the complete article was retrieved and checked.

\section{Quality assessment}

The quality of the studies was assessed using a quality assessment list (table 1), based on lists used in earlier reviews of observational studies $(22,25)$. The items on the list were rated as + (minimal requirements met),(minimal requirements not met) or ? (unclear whether the minimal requirements were met). For all the studies, the number of positive items was calculated. Studies were rated as high in quality if they scored positive on at least $50 \%$ of the relevant items. Two reviewers (WH and MP) separately evaluated the quality of the studies. A consensus meeting was arranged to sort out differences between the reviewers.

\section{Data extraction}

From all the studies, information on design, population, response rate, exposure, outcome, and the risk estimates [relative risk (RR), odds ratio (OR)] were extracted for the men and women. When risk estimates were not presented, but enough data were given, the risk estimates were calculated. When multiple outcome measures were presented, for example, pain and sick leave, the outcome closest to the complaint level was used in the analysis.

When it is being determined whether there was a gender difference for a risk factor, it is not sufficient for a risk estimate to be statistically significant in one group and not in another. It is also not correct to say that, if confidence intervals overlap, the risk estimates are not significantly different (26). Therefore, we divided the risk for women by the risk for men in order to calculate a gender ratio. A ratio higher than 1.25 (ie, women had a higher risk) or lower than 0.75 (ie, women had a lower risk) was regarded as a relevant gender difference.

It was anticipated that a wide variety of risk factors would be found in the various studies. Therefore, on the basis of the results of several recent reviews (20-24, 2732 ), we selected certain risk factors and used them in 
the analysis. The following tasks and job characteristics were considered physical risk factors: (i) lifting, manual materials handling, patient handling, awkward posture, bending and twisting, heavy physical workload, and whole-body vibration for the back; (ii) repetition, hand-arm vibration, arm posture, arm force, and head posture for the neck-shoulder region; (iii) repetition, vibration, wrist posture, and use of force for the handwrist region; and (iv) heavy physical work, kneeling or squatting, walking, and climbing for the lower extremities. Job demands, job control, social support, and job satisfaction were considered psychosocial risk factors for all the regions of the body under study.

\section{Levels of evidence}

Based on the reviews of Ariëns et al (22) and Hoogendoorn et al (25), the following four levels of evidence were constructed to determine the strength of evidence for a gender difference: (i) strong evidence, comprised of consistent gender differences in multiple high-quality cohort or case-control studies; (ii) moderate evidence, consistent gender differences found in one high-quality cohort or case-control study and at least one low-quality cohort or case-control study or consistent gender differences found in multiple low-quality cohort or casecontrol studies or consistent gender differences found in multiple high-quality cross-sectional studies; (iii) inconclusive evidence, consistent gender differences found in multiple low-quality cross-sectional studies or inconsistent results found in multiple studies or results based on one study; and (iv) no evidence of a difference, consistently no gender differences found. The results were regarded as consistent if at least $75 \%$ of the results were in the same direction.

\section{Results}

\section{Selection of the literature}

The search resulted in a total of 1653 articles. After the exclusion of doubles, 1473 titles and abstracts were reviewed for their relevance. Initially, there was a $7 \%$ disagreement between the reviewers about whether a paper met the inclusion criteria. After these disagreements were resolved, the full text of 185 articles was retrieved. On the basis of the full text, we included 31 studies. Another nine studies were included on the basis of the snowball search, the reference check, and perusal of personal databases.

Eight studies (33-40) were excluded after the data extraction because they did not present a risk estimate or there were not enough data to calculate one. Two studies $(41,42)$ were excluded because they did not
Table 1. Items used for scoring methodological quality. (ICC = intraclass correlation)

$\begin{array}{cc}\text { Cohort } & \begin{array}{c}\text { Case- } \\ \text { control }\end{array} \text { Sectional }\end{array}$

Design

1. Participation rate at baseline at least $80 \%$ or not selective

Population

2. Cases and controls drawn from the same population and clear definition of cases and controls stated

3. Response after 1-year follow-up at least $80 \%$ or the nonresponse not selective

Exposure assessment

4. Data on physical load at work collected and used in the analysis

5. Data on physical load collected using standardized methods of acceptable quality ${ }^{\mathrm{a}}$

6. Data on psychosocial load at work collected and used in the analysis

7. Data on psychosocial load collected using standardized methods of acceptable quality ${ }^{a}$

8. Data on historical exposure at work collected and used in the analysis ${ }^{b}$

9. Data on physical load during leisure time collected and used in the analysis

10. Data on psychosocial load during leisure time collected and used in the analysis

11. Exposure assessment blinded with respect to disease status

12. Exposure measured in an identical way for the cases and controls

13. Exposure assessed prior to the occurrence of the outcome

14. Data on history of (relevant) musculoskeletal complaints collected and used in the analysis

\section{Outcome assessment}

15. Data on outcome collected with standardized methods of acceptable quality ${ }^{c}$

16. Incident cases used

17. Data on outcome collected for at least 1 year

18. Data on outcome collected at least every 3 months or from a continuous registration system

Analysis

19. Statistical model appropriate for the outcome studied and a measure of association (including confidence intervals) presented

20. Study controlled for confounding ${ }^{d}$

21. Number of cases in the multivariate analysis at least 10 times the number of independent variables

Maximum score

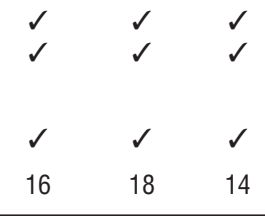

a Information in article of reference: direct measurements: ICC $>0.6$ or kappa $>0.4$; observations: ICC $>0.6$ or kappa $>0.4$ for inter- or intraobserver reliability; self report: ICC $>0.6$ or kappa $>0.4$ for inter- or intraobserver reliability.

b Only years of employment in current job not enough. At least several jobs or exposure in a certain time period should have been given.

c Self report: ICC $>0.6$ or kappa $>0.4$ for test-retest reliability; registration system: data should show a valid and reliable system. Physical examination: ICC $>0.6$ or kappa $>0.4$ for inter- or intraobserver reliability.

${ }^{d}$ At least corrected for age and (if applicable) different worksites. 
report musculoskeletal complaints for a specific region. Finally, four studies (43-46) that met all the inclusion criteria and presented their data in a usable way could not be used in the analysis because they did not report findings in respect to any of the predetermined risk factors. Therefore, 14 studies (47-60) on back complaints, 9 studies (58-66) on neck-shoulder complaints, 4 studies (65-68) on hand-wrist complaints and 4 studies (6972) on lower-extremity complaints were used. A description of the studies that were used is given in the appendix. Only relevant outcome and exposure measures are presented.

\section{Quality assessment}

The overall agreement between the two reviewers was $86 \%$ (kappa 0.76), and the agreement for the individual items ranged from $50 \%$ (item 18) to $100 \%$ (item 6, 14 , and 19). All disagreements were resolved in the consensus meeting. In table 2 an overview of the scoring

Table 2. Scoring used for the methodological quality of the studies included in this review. See table 1 for a description of the items. $(+=$ study described the item and met the minimum requirements, $-=$ study described the item but did not meet the minimum requirements, ? = the item was not clearly described or it was not clear whether the minimum requirements were met; · = not applicable)

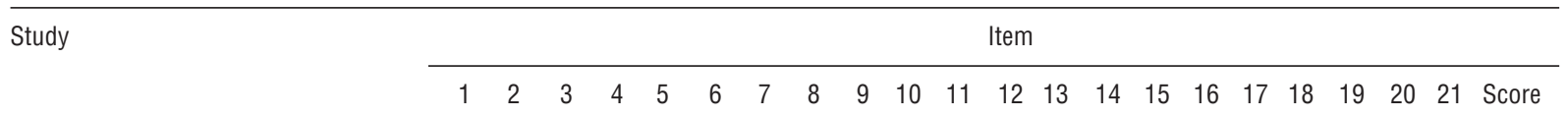

Bildt-Thorbjörnsson et al, 1998 (59);

Köster et al, 1999 (79); Fredriksson et al,

1999 (80, 81); Bildt-Thorbjörnsson et al,

2000 (82); Torgen et al 1997 (83); Bildt-

Thorbjörnsson et al, 1999 (84)

Cohort study

Case-control study

Vingard et al, 1999 (60); Tornqvist et al,

2001 (85); Vingard et al, 2000 (86); Wik-

torin et al, 1996 (87); Waldenstrom et al,

1998 (88); Wiktrorin et al, 1996 (89);

Wiktorin et al, 1999 (90); Torgén et al,

1999 (91); Mortimer et al, 1998 (92)

Mäkelä et al, 1991 (64); Mäkelä et al,

1999 (93)

Cassou et al, 2002 (61)

Cole et al, 2001 (48); Dollard \&

Winefield, 1998 (94)

Hemingway et al, 1997 (51)

Alcouffe et al, 1999 (47)

Barnekow-Bergkvist et al, 1998 (58)

Walsh et al, 1989 (56)

Coggon et al, 2000 (69)

Heliövaara, 1987 (50)

Manninen et al, 2002 (72)

Macfarlane et al, 1997 (54); Croft et al,

1999 (95); Papageorgiou et al, 1997

(96); Papageorgiou et al, 1995 (97)

Foppa \& Noach, 1996 (49)

Walsh et al, 1991 (57)

Coggon et al, 1998 (70)

Lau et al, 2000 (71); Cooper et al,

1994 (98)

Jensen et al, 2002 (65);, 99)

Matsui et al, 1997 (55)

Tanaka et al, 1995 (68); Tanaka et al,

2001 (100); Tanaka et al, 1997 (101)

Palmer et al, 2001 (62); Palmer et al, 2000 (75)

Fransson-Hall et al, 1995 (67)

Karlqvist et al, 2002 (66)

Latza et al, 2000 (53); Michel et al,

1997 (102)

Pope et al, 1997 (63) a

Kelsey, 1975 (52, 103); Kelsey \& Hardy, 1997 (104)
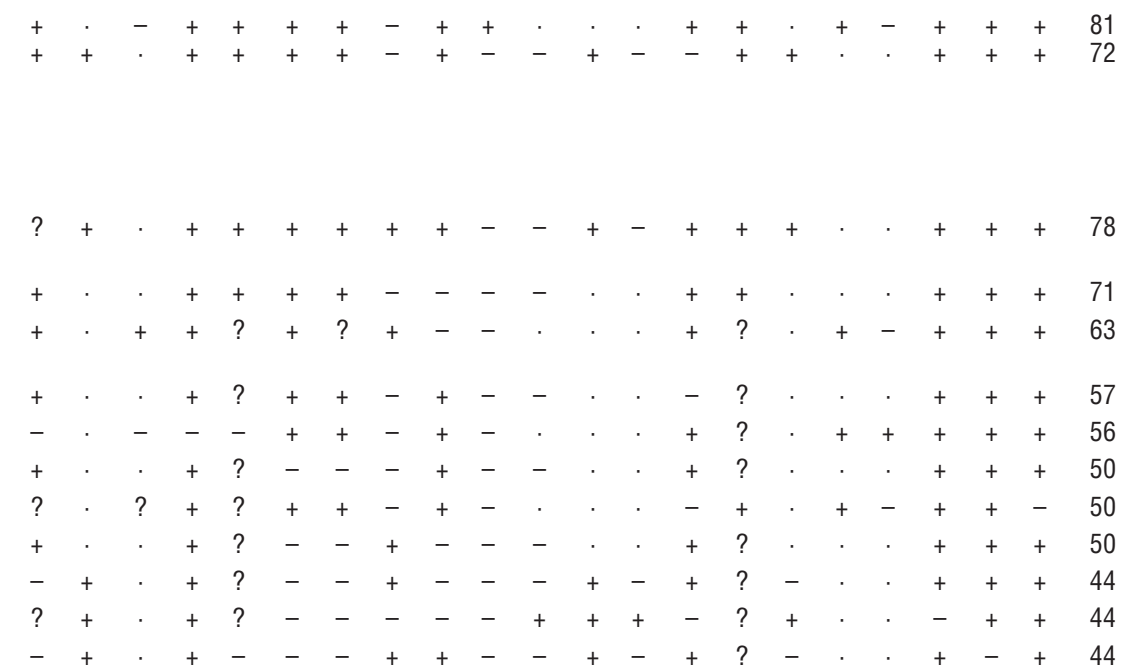

a The article stated a case-control design, but since we found the matching procedure questionable, the study was regarded as cross-sectional. 
of the individual studies is given. Three out of seven cohort studies were regarded as high in quality. For the case-control studies, again, three out of seven studies were of high quality. The study of Bildt-Thorbjörnsson et al (59), which consisted of a cohort and a case-control part, was regarded as high in quality for both designs. Only 4 of the 15 cross-sectional studies were of high quality.

\section{Back complaints}

A summary of the determination of the levels of evidence for back complaints can be found in table 3. Eight studies $(47,52-54,56-58,60)$ concerned lifting. The high-quality cohort study (58) found a gender ratio of 0.18 , while, in the high-quality case-control study (60), gender ratios of 0.57 and 0.80 were found for heavy lifting and manual materials handling, respectively. The low-quality cohort and case-control studies $(52,54)$ and a high-quality cross-sectional study (47) found gender ratios between 1.35 and 2.27. The second high-quality cross-sectional study (56) and a low-quality cross-sectional study (57) found no difference between men and women, while, in another low-quality cross-sectional study (53), a ratio of 0.55 was found. On the basis of the results of the high-quality cohort and case-control studies, we concluded that there is strong evidence that men have a higher risk of back complaints due to lifting than women do.

Posture was investigated in four studies $(47,53$, $58,60)$. The high-quality cohort study (58) and the

Table 3. Summary of the determination of levels of evidence for back complaints. ( $M Q=$ methodological quality, $H Q=$ high quality, $L Q=$ low quality)

\begin{tabular}{|c|c|c|c|c|c|c|c|c|}
\hline \multirow[t]{3}{*}{ Risk factor } & \multirow[t]{3}{*}{$M Q$} & \multicolumn{6}{|c|}{ Direction of the difference } & \multirow{3}{*}{$\begin{array}{l}\text { Level of } \\
\text { - evidence }\end{array}$} \\
\hline & & \multicolumn{2}{|c|}{ Male>female } & \multicolumn{2}{|c|}{ Male=female } & \multicolumn{2}{|c|}{ Female $>$ male } & \\
\hline & & $\begin{array}{l}\text { Case-control } \\
\text { or cohort }\end{array}$ & $\begin{array}{l}\text { Cross- } \\
\text { sectional }\end{array}$ & $\begin{array}{l}\text { Case-control } \\
\text { or cohort }\end{array}$ & $\begin{array}{l}\text { Cross- } \\
\text { sectional }\end{array}$ & $\begin{array}{l}\text { Case-control } \\
\text { or cohort }\end{array}$ & $\begin{array}{l}\text { Cross- } \\
\text { sectional }\end{array}$ & \\
\hline \multirow[t]{2}{*}{ Lifting } & $\mathrm{HQ}$ & $\begin{array}{l}\text { Vingard et al } \\
\text { (60); Barnekow- } \\
\text { Bergkvist et al } \\
\text { (58) }\end{array}$ & . & $\begin{array}{l}\text { Walsh et al } \\
(56)\end{array}$ & . & $\cdot$ & $\begin{array}{l}\text { Alcouffe et } \\
\text { al (47) }\end{array}$ & $\begin{array}{l}\text { Strong } \\
\text { evidence, male } \\
\text { greater than } \\
\text { female }\end{array}$ \\
\hline & $\mathrm{LQ}$ & . & Latza et al (53) & $\cdot$ & Walsh et al (57) & $\begin{array}{l}\text { Kelsey (52); } \\
\text { Macfarlane et } \\
\text { al (54) }\end{array}$ & - & $\cdot$ \\
\hline \multirow[t]{2}{*}{$\begin{array}{l}\text { Awkward } \\
\text { postures }\end{array}$} & $\mathrm{HQ}$ & $\begin{array}{l}\text { Vingard et al } \\
(60)\end{array}$ & $\cdot$ & $\begin{array}{l}\text { Barnekow-Berg- } \\
\text { kvist et al (58) }\end{array}$ & $\begin{array}{l}\text { Alcouffe et al } \\
(47)\end{array}$ & . & . & $\begin{array}{l}\text { Inconclusive } \\
\text { evidence }\end{array}$ \\
\hline & LQ & · & Latza et al (53) & $\cdot$ & $\cdot$ & . & . & $\cdot$ \\
\hline \multirow[t]{2}{*}{$\begin{array}{l}\text { Heavy physical } \\
\text { work }\end{array}$} & $\mathrm{HQ}$ & . & $\cdot$ & $\begin{array}{l}\text { Bildt-Thorbjörns- } \\
\text { son et al (59) }\end{array}$ & $\begin{array}{l}\text { - Barnekow-Berg- } \\
\text { kvist et al (58) }\end{array}$ & $\begin{array}{l}\text { Vingard et al } \\
(60)\end{array}$ & . & $\begin{array}{l}\text { Inconclusive } \\
\text { evidence }\end{array}$ \\
\hline & LQ & . & . & . & $\begin{array}{l}\text { Foppa \& Noach } \\
(49)\end{array}$ & $\begin{array}{l}\text { Heliövaara (50); } \\
\text { Matsui et al (55) }\end{array}$ & & $\cdot$ \\
\hline \multirow[t]{2}{*}{$\begin{array}{l}\text { Whole-body } \\
\text { vibration }\end{array}$} & $\mathrm{HQ}$ & $\begin{array}{l}\text { Barnekow-Berg- } \\
\text { kvist et al (58) }\end{array}$ & Walsh et al (56) & . & . & $\begin{array}{l}\text { Vingard et al } \\
(60)\end{array}$ & Walsh et al (56) & $\begin{array}{l}\text { Inconclusive } \\
\text { evidence }\end{array}$ \\
\hline & $\mathrm{LQ}$ & $\cdot$ & $\cdot$ & $\begin{array}{l}\text { Kelsey (52); } \\
\text { Macfarlane et } \\
\text { al (54) }\end{array}$ & . & $\cdot$ & Walsh et al (57) & - \\
\hline \multirow[t]{2}{*}{ Job demands } & $\mathrm{HQ}$ & $\cdot$ & $\cdot$ & $\begin{array}{l}\text { Hemingway } \\
\text { et al }(51) ; \\
\text { Bildt-Thorbjörns- } \\
\text { son et al (59) }\end{array}$ & - & $\begin{array}{l}\text { Barnekow- } \\
\text { Bergkvist et } \\
\text { al (58) }\end{array}$ & Cole et al (48) & $\begin{array}{l}\text { Inconclusive } \\
\text { evidence }\end{array}$ \\
\hline & $\mathrm{LQ}$ & . & . & $\cdot$ & $\begin{array}{l}\text { Foppa \& Noach } \\
\text { (49) }\end{array}$ & . & . & . \\
\hline \multirow[t]{2}{*}{ Job control } & $\mathrm{HQ}$ & $\begin{array}{l}\text { Hemingway } \\
\text { et al }(51)\end{array}$ & . & $\begin{array}{l}\text { Vingard et al } \\
(60)\end{array}$ & $\begin{array}{l}\text { Alcouffe et al } \\
(47) ; \text { Cole et al } \\
(48)\end{array}$ & $\begin{array}{l}\text { Barnekow- } \\
\text { Bergkvist et } \\
\text { al (58) }\end{array}$ & . & $\begin{array}{l}\text { Inconclusive } \\
\text { evidence }\end{array}$ \\
\hline & $\mathrm{LQ}$ & . & . & . & . & . & . & . \\
\hline \multirow[t]{2}{*}{ Job satisfaction } & $\mathrm{HQ}$ & $\begin{array}{l}\text { Vingard et al } \\
(60)\end{array}$ & . & $\begin{array}{l}\text { Hemingway et } \\
\text { al (51); Barne- } \\
\text { kow-Bergkvist } \\
\text { et al (58) }\end{array}$ & . & $\cdot$ & . & $\begin{array}{l}\text { Inconclusive } \\
\text { evidence }\end{array}$ \\
\hline & LQ & . & . & $\cdot$ & $\begin{array}{l}\text { Foppa \& Noach } \\
(49)\end{array}$ & $\cdot$ & . & . \\
\hline \multirow[t]{2}{*}{ Social support } & $\mathrm{HQ}$ & . & . & $\begin{array}{l}\text { Hemingway } \\
\text { et al (51); } \\
\text { Bildt-Thor- } \\
\text { björnsson et } \\
\text { al (59); Vingard } \\
\text { et al (60) }\end{array}$ & Cole et al (48) & $\begin{array}{l}\text { Barnekow- } \\
\text { Bergkvist et al } \\
(58)\end{array}$ & . & $\begin{array}{l}\text { No evidence of } \\
\text { a difference }\end{array}$ \\
\hline & $\mathrm{LQ}$ & . & . & . & . & . & . & . \\
\hline
\end{tabular}


high-quality cross-sectional study (47) found no difference between men and women. The high-quality casecontrol study (60) and the low-quality cross-sectional study (53) showed risk ratios of 0.67 and 0.40 , respectively. Since the results of the high-quality cohort and case-control studies were not consistent, there is inconclusive evidence for a gender difference for posture.

Four case-control $(50,55,59,60)$ and two cross-sectional $(48,49)$ studies reported on heavy physical work as a risk factor for back pain. One high-quality (60) and two low-quality case-control $(50,55)$ studies found a larger risk for women (gender ratios ranging from 1.36 to 3.43). No difference in the risk estimate between men and women was found in the other high-quality casecontrol study (59) and the cross-sectional studies (48, 49). Since these results were not consistent, there is inconclusive evidence for a gender difference for heavy physical workload.

Whole-body vibration, measured as vibration or driving, was investigated in six studies $(52,54,56-58$, $60)$. The high-quality case-control (60) and the lowquality cross-sectional (57) studies found gender ratios of 3.11 and 1.40, respectively. However, the high-quality cohort study (58) found a gender ratio of 0.58 . In the high-quality cross-sectional study (56), gender ratios of $0.24-0.67$ for driving, and a gender ratio of 3.80 for exposure to vibration machinery, were found. Finally, the low-quality cohort (54) and case-control (52) studies did not find a gender difference. Since these results were not consistent, there is inconsistent evidence of a gender difference for whole-body vibration.

Job demands were assessed in five studies (48, 49, $51,58,59)$. One high-quality cohort study $(58)$ and one high-quality cross-sectional study (48) found gender ratios of 1.90 and 1.35 respectively. The second high-quality cohort study (51), the high-quality case-control study (59), and a low-quality cross-sectional study (49) did not find a gender difference. Due to the inconsistency of these results there is inconclusive evidence of a gender difference for job demands.

Five high-quality studies $(47,48,51,58,60)$ examined job control. One cohort study (58) found a gender ratio of 1.35, while, for the other cohort study (51), a gender ratio of 0.70 was calculated. The case-control study $(60)$ and both cross-sectional studies $(47,48)$ did not find a gender difference. Because of the inconsistency of these results, there is inconclusive evidence for a gender difference for job control.

A gender ratio of 1.41 for social support as a risk factor was found in a high-quality cohort study (58). However, the other high-quality cohort study (51), both high-quality case-control studies $(59,60)$, and the highquality cross-sectional study (48) did not find a gender difference. The conclusion, therefore, is that there is no evidence of a gender difference.
A gender difference in the relation between job satisfaction and back pain was only found in one high-quality case-control study (60), with a gender ratio of 0.33 . No gender difference was found in two high-quality cohort studies $(51,58)$ and one low-quality cross-sectional study (49). Due to the inconsistency in the high-quality studies, there is inconclusive evidence for a gender difference for job satisfaction.

\section{Neck-shoulder complaints}

Table 4 provides an overview of the determination of the levels of evidence for neck-shoulder complaints. A total of five studies $(59-61,63)$ assessed the relation between repetition and neck-shoulder complaints. One high-quality case-control study (60) found a gender ratio of 1.33 , while the second high-quality case-control study (59) did not find a gender difference. The highquality cohort study (61) found a gender ratio of 1.44 for the exposure at baseline, but no difference for exposure before baseline. The results of the low-quality cross-sectional studies $(63,65)$ were not consistent either, with gender ratios of $0.53-2.34$, depending on the exact outcome and exposure. Because of these inconsistent results, there is inconclusive evidence for a gender difference for repetition.

The relation between hand-arm vibration and neckshoulder complaints was measured in four studies (59, $60,62,63)$. Both high-quality case-control studies (59, 60 ) and one low-quality cross-sectional study (63) found a larger risk for men (gender ratios $0.50,0.54$ and 0.73 , respectively). The second low-quality cross-sectional study (62) found a gender ratio of 0.22 for pain in the past 7 days, but no difference for pain in the past 12 months. Because the case-control studies $(59,60)$ consistently showed a higher risk estimate for men, it is concluded that there is strong evidence that exposure to hand-arm vibration is a larger risk for men.

Arm posture was investigated in one high-quality cohort study (58), one high-quality case-control study $(60)$, and three low-quality cross-sectional studies (62, $63,66)$. The cohort and case-control studies found larger risk estimates for women, with gender ratios of 6.39 (58) and 1.44 (60). The cross-sectional studies found no difference between men and women $(62,66)$ or a larger risk for men (63). The results of the cohort (58) and case-control (60) studies indicate that there is strong evidence that exposure to awkward arm postures is a larger risk factor for women than for men.

Arm force, measured as lifting, was measured in one high-quality cohort study (58), one high-quality casecontrol study (60), and two low-quality cross-sectional studies $(62,63)$. The case-control study (60) and one of the cross-sectional studies (63) found a larger risk for men (gender ratios from 0.20 to 0.67 ). No gender 
Table 4. Summary of the determination of levels of evidence for neck-shoulder complaints. $(\mathrm{MQ}=$ methodological quality score, $\mathrm{HQ}=$ high quality, $L Q=$ low quality)

\begin{tabular}{|c|c|c|c|c|c|c|c|c|}
\hline \multirow[t]{3}{*}{ Risk factor } & \multirow[t]{3}{*}{$M Q$} & \multicolumn{6}{|c|}{ Direction of the difference } & \multirow{3}{*}{$\begin{array}{l}\text { Level of } \\
\text { evidence }\end{array}$} \\
\hline & & \multicolumn{2}{|c|}{ Malesfemale } & \multicolumn{2}{|c|}{ Male=female } & \multicolumn{2}{|c|}{ Female $>$ male } & \\
\hline & & $\begin{array}{l}\text { Case-control/ } \\
\text { cohort }\end{array}$ & $\begin{array}{l}\text { Cross- } \\
\text { sectional }\end{array}$ & $\begin{array}{l}\text { Case-control/ } \\
\text { cohort }\end{array}$ & $\begin{array}{l}\text { Cross- } \\
\text { sectional }\end{array}$ & $\begin{array}{l}\text { Case-control/ } \\
\text { cohort }\end{array}$ & $\begin{array}{l}\text { Cross- } \\
\text { sectional }\end{array}$ & \\
\hline \multirow[t]{2}{*}{ Repetition } & $\mathrm{HQ}$ & - & - & $\begin{array}{l}\text { Cassou et al } \\
(61)^{\text {ad }} \text { Bildt- } \\
\text { Thorbjörns- } \\
\text { son et al (59) }\end{array}$ & . & $\begin{array}{l}\text { Vingart et al } \\
(60) ; \text { Cassou et } \\
\text { al (61) }{ }^{b}\end{array}$ & - & $\begin{array}{l}\text { Inconclusive } \\
\text { evidence }\end{array}$ \\
\hline & $\mathrm{LQ}$ & . & Pope et al (63) ${ }^{d}$ & $\cdot$ & $\begin{array}{l}\text { Jensen et al } \\
(65)^{e} \text {; Pope et al } \\
(63)^{c}\end{array}$ & . & Jensen et al $(65)^{f}$ & . \\
\hline \multirow[t]{2}{*}{$\begin{array}{l}\text { Hand-arm } \\
\text { vibration }\end{array}$} & $H Q$ & $\begin{array}{l}\text { Bildt-Thor- } \\
\text { björnsson et } \\
\text { al (59); Vingard } \\
\text { et al (60) }\end{array}$ & . & - & . & . & . & $\begin{array}{l}\text { Strong } \\
\text { evidence, male } \\
\text { greater than } \\
\text { female }\end{array}$ \\
\hline & $\mathrm{LQ}$ & . & Pope et al (63) & . & Palmer et al (62) & $\cdot$ & . & \\
\hline \multirow[t]{2}{*}{ Arm posture } & $\mathrm{HQ}$ & . & . & - & . & $\begin{array}{l}\text { Barnekow- } \\
\text { Bergkvist et al } \\
\text { (58); Vingard et } \\
\text { al (60) }\end{array}$ & . & $\begin{array}{l}\text { Strong } \\
\text { evidence, } \\
\text { female greater } \\
\text { than male }\end{array}$ \\
\hline & $\mathrm{LQ}$ & . & Pope et al (63) & - & $\begin{array}{l}\text { Palmer et al (62); } \\
\text { Karlqvist (66) }\end{array}$ & . & . & . \\
\hline \multirow[t]{2}{*}{ Arm force } & $\mathrm{HQ}$ & $\begin{array}{l}\text { Vingard et } \\
\text { al (60) }\end{array}$ & . & $\begin{array}{l}\text { Barnekow-Berg- } \\
\text { kvist et al (58) }\end{array}$ & . & . & . & $\begin{array}{l}\text { Inconclusive } \\
\text { evidence }\end{array}$ \\
\hline & $\mathrm{LQ}$ & $\cdot$ & Pope et al (63) & $\cdot$ & Palmer et al (62) & . & . & \\
\hline \multirow[t]{2}{*}{ Job demands } & $H Q$ & $\begin{array}{l}\text { Barnekow-Berg- } \\
\text { kvist et al (58) }\end{array}$ & . & $\begin{array}{l}\text { Cassou et al } \\
(61)\end{array}$ & Mäkelä et al (64) & $\begin{array}{l}\text { Bildt-Thor- } \\
\text { björnsson et } \\
\text { al (59); Vingard } \\
\text { et al (60) }\end{array}$ & - & $\begin{array}{l}\text { Inconclusive } \\
\text { evidence }\end{array}$ \\
\hline & $\mathrm{LQ}$ & $\cdot$ & . & . & $\begin{array}{l}\text { Jensen et al (65); } \\
\text { Karlqvist (66) }\end{array}$ & $\cdot$ & $\cdot$ & $\cdot$ \\
\hline \multirow[t]{2}{*}{ Job control } & $\mathrm{HQ}$ & - & - & $\begin{array}{l}\text { Vingard et } \\
\text { al (60) }\end{array}$ & . & $\begin{array}{l}\text { Barnekow-Berg- } \\
\text { kvist et al (58); } \\
\text { Bildt-Thor- } \\
\text { björnsson et } \\
\text { al (59) }\end{array}$ & . & $\begin{array}{l}\text { Inconclusive } \\
\text { evidence }\end{array}$ \\
\hline & $\mathrm{LQ}$ & . & . & . & . & . & . & . \\
\hline \multirow[t]{2}{*}{ Social support } & $\mathrm{HQ}$ & . & . & $\begin{array}{l}\text { Barnekow-Berg- } \\
\text { kvist et al (58); } \\
\text { Vingard et al (60) }\end{array}$ & & . & . & $\begin{array}{l}\text { No evidence for } \\
\text { a difference }\end{array}$ \\
\hline & $\mathrm{LQ}$ & . & . & . & Karlqvist (66) & . & . & . \\
\hline
\end{tabular}

difference was found in the second cross-sectional study (62) and the cohort study (58), in which men and women with a heavy lift index had a lower risk of neckshoulder complaints. Therefore, the evidence is inconclusive.

Job demands were investigated in seven studies (5861, 64-66). One high-quality cohort study (58) found a gender ratio of 0.64 , but the two high-quality case-control studies $(59,60)$ found gender ratios from 1.57 to 4.50. No gender difference was found in the second high-quality cohort study (61) and the cross-sectional studies (64-66). Since these results were not consistent, there is inconclusive evidence of a gender difference for job demands.

Three high-quality studies (58-60) measured job control. One case-control study (60) found no gender difference, but the second case-control study (59) found a gender ratio of 5.0. The gender ratio in the cohort study (58) was 1.33. Due to the inconsistency of the results, there is inconclusive for a gender difference for job control.

One high-quality cohort (58), one high-quality casecontrol (60), and one low-quality cross-sectional (66) study concerned social support. Since none of them found differences between men and women, it is concluded that there is no evidence for a gender difference.

\section{Hand-wrist complaints}

Two low-quality cross-sectional studies $(65,67)$ concerned repetitive movements. Since only one of them (67) found a gender difference (gender ratio 1.29), there is inconclusive evidence for a gender difference. 
One study (68) focused on the relation between vibration and hand-wrist complaints (gender ratio 0.49), but, since this was a low-quality cross-sectional study, there is inconclusive evidence of a gender difference.

Three cross-sectional studies (66-68) concentrated on wrist postures. One of them (67) found gender differences, with ratios of 0.71 and 1.29 depending on the exact exposure, but the other two studies found no gender differences. Since these results were inconsistent and the studies were low in quality, there is inconclusive evidence for a gender difference.

Job demands were measured in two studies $(65,66)$, but only one of them (66) found a gender difference. Due to the inconsistency and the low quality of the studies, there is inconclusive evidence of a gender difference.

One low-quality cross-sectional study (66) reported the relation between social support and hand-wrist complaints. No gender difference was found, but, since the results were based on only one study, there is inconclusive evidence for a gender difference.

\section{Lower-extremity complaints}

Only one low-quality study (72) reported a relation between heavy physical workload and lower-extremity complaints. This study found a gender ratio of 1.33 . With only one study, there is inconclusive evidence of a gender difference.

Four low-quality case-control studies (69-72) reported on kneeling or squatting. Two studies $(69,72)$ used exposures that combined kneeling and squatting. Neither study found a gender difference. Two studies $(70,71)$ found a gender difference for kneeling (gender ratio $0.33-0.64$ ), and, in one study (69), a gender ratio of 1.27 was found for squatting. Since the results of these studies were not consistent, there is inconclusive evidence for a gender difference for kneeling or squatting.

Much walking was a larger risk factor for men in two out of four low-quality case-control studies (71, 72 ), with gender ratios from 0.36 to 0.72 . The third study showed no difference between men and women, while, in the fourth, gender ratios of 1.36 and 1.88 were found. Due to the inconsistency of the results, there is inconclusive evidence for a gender difference for walking.

Climbing was measured in four low-quality casecontrol studies (69-72). Two studies (69-72) found a larger risk for men (gender ratios $0.30-0.54$ ). In one study (71) the direction of the gender difference depended on the outcome (gender ratio 0.18 for hip complaints and 2.04 for knee complaints), and in one study (70) the direction was dependent on the duration of the exposure (gender ratios $0.57-1.28$ ). Since these results were not consistent, there is inconclusive evidence of a gender difference for climbing.

\section{Discussion}

The purpose of this review was to examine gender differences in the effect of exposure to work-related physical and psychosocial risk factors. Considering the gender differences in prevalence, we expected that women would have higher risks. The results show evidence of a gender difference for a few risk factors, but in most cases men had the higher risk.

\section{Back complaints}

Before the study, we presumed that women would have a higher risk of back complaints due to lifting than men, but we found strong evidence that men have a higher risk. However, it could be argued that, since the weight of the average larger male torso has to be added to the weight of the lifted object, men in fact have a higher exposure than women when lifting an equal object. This difference may be one factor leading to a higher risk of back complaints among men. Several studies (18, 73, 74 ) indeed found that men have a greater absolute exposure, due to their greater body mass. However, these same studies also showed that women are not merely scaled-down versions of men, but, in fact, use different techniques while lifting. In the end, this difference resulted in a greater relative workload for women and, therefore, in a greater risk of complaints. Another remarkable point is that Vingard et al (60) found a (not significant) relative risk of 0.8 for women, while Barnekow-Bergkvist et al (58) found odds ratios of $<1$ for both men and women. This evidence is clearly in contrast to the generally accepted view that lifting is a risk factor for back pain $(23,32)$. It should be mentioned, however, that the study population in this last study was relatively young [mean age 34 (SD 0.74) years]. Together with the possible selection bias of this study, the young age may explain the unexpected result. Finally, although the high-quality cohort and case-control studies found gender ratios below 0.75 , the low-quality cohort and case-control studies consistently found ratios above 1.25. Therefore, the conclusion that men have a higher risk than women due to lifting should be considered with due caution.

\section{Neck-shoulder complaints}

As for back complaints, it was expected that women would have a higher risk. This was indeed the case for arm posture, but for hand-arm vibration men had the higher risk. The studies in our review used a rather low cut-off point for exposure (30 minutes and $16 \%$ of the time); hence a large range of exposures within the highest exposure category was possible. Total daily exposure to vibration has been found to be much higher for 
men than for women (75), and, therefore, men may still have had a higher exposure than women within the same exposure category. Furthermore, the effect of vibration on complaints may be rather small for women, since the 1-week prevalence of exposure was found to be only $6 \%$ for working women, but $32 \%$ for working men (75).

\section{Hand-wrist complaints}

Very few studies on hand-wrist complaints were found. Although initially nine studies were identified, four were excluded because they did not report findings for the selected risk factors. Three studies $(44,65,66)$ considered the duration of computer use as a risk factor, but the results were not consistent. While, in the study by Blatter et al (44), the risk was larger for women (gender ratios ranging from 1.05 to 1.38 ), Jensen et al (65) and Karlqvist et al (66) found larger risks for men (ratios ranging from 0.55 to 0.99 ). Nevertheless, only a few studies reported risk factors for men and women separately, and the reason for the inconclusiveness should primarily be sought in the lack of (high-quality) studies. Furthermore, since all these studies were cross-sectional, no causal relation could be established. It is recommended that more, preferably prospective, studies on hand-wrist complaints make separate analyses for men and women.

\section{Lower-extremity complaints}

Due to the inconsistency and the small number of lowquality studies, inconclusive evidence was found for all the risk factors for lower-extremity complaints. As for hand-wrist complaints, we would like to emphasize the need for more (high-quality) studies.

\section{Selection of the literature}

To our knowledge this is the first review that systematically examined gender differences in the relation between work-related risk factors and musculoskeletal complaints. In spite of our extensive literature search, it is likely that both selection and publication bias influenced the results. Most studies on risk factors do not aim at examining gender differences and do not use key words referring to such differences. By including the terms gender (difference) and sex (difference) in the search string, we may have missed these studies. Another potential source of bias is publication bias. While some studies tested for all possible interactions or made separate analyses for all risk factors, most of the studies only did this for a few variables. It could very well be that such an approach was only used because (significant) gender differences were found for these risk factors. The results of this review may therefore overestimate gender differences.

\section{Analysis}

We chose to use a percentage difference in risk estimates rather than an absolute number or a significant difference to identify relevant differences. However, we could not find theoretical grounds for the point of cut-off. By using the percentage difference, we had to exclude studies that did not present risk estimates and those which only reported a nonsignificant difference. Four of these studies did mention that there was no difference between men and women, or no significant interaction with gender was found (37-40). One study (37) assessed the relation between lifting and back complaints, three studies concerned job demands and neck-shoulder complaints (38-40), while job control, social support, and work with hands above shoulder level were each assessed in one study $(39,40)$. Considering these studies did not change the strength of the evidence.

\section{Methodological quality and levels of evidence}

The combination of a quality scale and levels of evidence is often used, but not without criticism $(76,77)$. Our quality list was very similar to lists used earlier (20, 22, 23, 25). One of these lists (22) was rated by West et al (78), and it scored positive on six and partially positive on one out of nine domains for assessing study quality. A point of criticism on this and similar lists is that all the items have the same weight, and studies that have only a few, but very important, flaws can still be regarded as high in quality $(21,22)$. In our review, the three studies with the highest quality $(59,60,64)$ scored positive on all items regarding validity of outcome and exposure measures. Another three high-quality studies $(48,51,58)$ scored positive on at least one of these items, while none of the lowquality studies scored positive on these items. Therefore, these items are important in discriminating between highand low-quality studies. Another point of criticism is that, when different levels of evidence are compared, their agreement is poor and may result in differences in the conclusion (76). Unfortunately, to our knowledge, no other levels of evidence for observational studies have been published, and no comparison can be made with our levels.

\section{Concluding remarks}

Strong evidence of a gender difference was found for only three risk factors, but for two out of three factors the difference was not in the expected direction. These findings seemed fairly insensitive to the limitations of our study, but are likely to be an overestimation of gender differences. Therefore, the results should be interpreted with some caution. For hand-wrist and lowerextremity complaints only a few low-quality studies were found, and it is recommended that more studies make separate analyses for men and women. 
Since gender differences in the effect of risk factors do not seem to provide an explanation for the higher prevalence of musculoskeletal complaints among women, alternative explanations have to be considered, such as gender differences in the number of workers exposed, in exposure within the same exposure category, or the expression of pain (8-11). In terms of prevention, until more clarity is achieved, the focus should remain on the reduction of exposure among female workers.

\section{References}

1. Picavet HSJ, van Gils HWV, Schouten JSGA. Klachten van het bewegingsapparaat in de Nederlandse bevolking: prevalenties, consequenties en risicogroepen [Musculoskeletal complaints in the Dutch population: prevalences, consequences and risk groups]. Bilthoven (The Netherlands): Rijksinstituut voor volksgezondheid en milieu (RIVM); 2000.

2. Linton SJ, Hellsing AL, Halldén K. A population-based study of spinal pain among 35-45-year-old individuals: prevalence, sick leave, and health care use. Spine 1998;23:1457-63.

3. Centers for Disease Control and Prevention (CDC). Prevalence of self-reported arthritis or chronic joint symptoms among adults-United States, 2001. MMWR Morb Mortal Wkly Rep 2002;51(42):948-50.

4. De Zwart BCH, Broersen JP, Frings-Dresen MH, van Dijk FJ. Musculoskeletal complaints in The Netherlands in relation to age, gender and physically demanding work. Int Arch Occup Environ Health 1997;70(5):352-60.

5. Gerr F, Marcus M, Ensor C, Kleinbaum D, Cohen S, Edwards A, et al. A prospective study of computer users, I: study design and incidence of musculoskeletal symptoms and disorders. Am J Ind Med 2002;41(4):221-35.

6. Krause N, Ragland DR, Greiner BA, Syme SL, Fisher JM. Psychosocial job factors associated with back and neck pain in public transit operators. Scand J Work Environ Health 1997;23(3):179-86.

7. Leino-Arjas $P$, Hänninen $K$, Puska P. Socioeconomic variation in back and joint pain in Finland. Eur J Epidemiol 1998;14:79-87.

8. Punnett L, Herbert R. Work-related musculoskeletal disorders: is there a gender differential, and if so, what does it mean? In: Goldman MB, Hatch MC, editors. Women and health. San Diego (CA): Academic Press; 2000. p 474-92.

9. Kilbom Å, Messing K. Aches and pains-an affliction of women: work-related musculoskeletal disorders. In: Kilbom $\AA$, Messing K, Bildt-Thorbjörnsson C, editors. Women's health at work. Solna (Sweden): National Institute for Working Life; 1998. p 203-27.

10. Buckle P, Devereux J. Work-related neck and upper limb disorders. Luxembourg: European Agency for Safety and Health at work; 1999.

11. Karlqvist L. The importance of gender sensitive studies of work related neck and upper limb disorders. In: Bild C, Karlqvist L, editors. Women's conditions in working life. Solna (Sweden): Arbetslivsinstitutet, 2001. p: 66-72. Arbete och hälsa 2001:17.

12. De Zwart BCH, Frings-Dresen MHW, Kilbom A. Gender differences in upper extremity musculoskeletal complaints in the working population. Int Arch Occup Environ Health
2000;74(1):21-30

13. Coury HJCG, Portcatti IA, Alem MER, Oisho J. Influence of gender on work-related musculoskeletal disorders in repetitive tasks. Int J Ind Ergon 2002;29:33-9.

14. Gijsbers van Wijk CMT, Kolk AM. Sex differences in physical symptoms: the contribution of symptom perception theory. Soc Sci Med 1997;45:231-46.

15. Musgrave DS, Vogt MT, Nevitt MC, Cauley JA. Back problems among postmenopausal women taking estrogen replacement therapy: the study of osteoporotic fractures. Spine 2001;26(14):1606-12.

16. Brynhildsen JO, Björs E, Skarsgård C, Hammar ML. Is hormone replacement therapy a risk factor for low back pain among postmenopausal women? Spine 1998;23(7):809-13.

17. Van der Beek AJ, Kluver BDR, Frings-Dresen MHW, Hoozemans MJM. Gender differences in exerted forces and energetic workload during pushing and pulling of wheeled cages by postal workers. Ergonomics 2000;43(2):269-81.

18. Lindbeck L, Kjellberg K. Gender differences in lifting technique. Ergonomics 2001;44(2):202-14.

19. Bellman S, Forster N, Still L, Cooper CL. Gender differences in the use of social support as a moderator of occupational stress. Stress Health 2003;19(1):45-58.

20. Ariëns GAM, van Mechelen W, Bongers PM, Bouter LM, van der Wal G. Psychosocial risk factors for neck pain: a systematic review. Am J Ind Med 2001;39(2):180-93.

21. Van der Windt DAWM, Thomas E, Pope DP, de Winter AF, Macfarlane GJ, Bouter LM, et al. Occupational risk factors for shoulder pain: a systematic review. Occup Environ Med 2000;75:433-42.

22. Ariëns GAM, van Mechelen W, Bongers PM, Bouter LM, van der Wal G. Physical risk factors for neck pain [review]. Scand J Work Environ Health 2000;26(1):7-19.

23. Hoogendoorn WE, van Poppel MNM, Bongers PM, Koes BW, Bouter LM. Physical load during work and leisure time as risk factors for back pain [review]. Scand J Work Environ Health 1999;25(5):387-403.

24. Bongers PM, Kremer AM, ter Laak J. Are psychosocial factors, risk factors for symptoms and signs of the shoulder, elbow, or hand/wrist?: a review of the epidemiological literature. Am J Ind Med 2002 May;41(5):315-42.

25. Hoogendoorn WE, van Poppel MN, Bongers PM, Koes BW, Bouter LM. Systematic review of psychosocial factors at work and private life as risk factors for back pain. Spine 2000;25(16):2114-25.

26. Altman DG, Bland MJ. Interaction revisited: the difference between two estimates. BMJ 2003;326:218.

27. Maetzel A, Mäkelä M, Hawker G, Bombardier C. Osteoarthritis of the hip and knee and mechanical occupational exposure - a systematic overview of the evidence. J Rheumatol 1997;24(8):1599-607.

28. Kirkeskov Jensen L, Eenberg W. Occupation as a risk factor for knee disorders [review]. Scand J Work Environ Health 1996;22(3):165-75.

29. Viikari-Juntura E, Silverstein B. Role of physical load factors in carpal tunnel syndrome [review]. Scand J Work Environ Health 1999;25(3):163-85.

30. Sluiter JK, Rest KM, Frings-Dresen MHW. Criteria document for evaluating the work-relatedness of upper-extremity musculoskeletal disorders. Scand J Work Environ Health 2001;27 Suppl 1:1-102.

31. Bernard BP, editor. Musculoskeletal disorders and workplace factors: a critical review of epidemiologic evidence for work-related musculoskeletal disorders of the neck, upper 
extremity, and low back. Cincinnati $(\mathrm{OH})$ : National Institute for Occupational Safety and Health (NIOSH); 1997.

32. Burdorf A, Sorock G. Positive and negative evidence of risk factors for back disorders [review]. Scand J Work Environ Health 1997;23(4):243-56.

33. Burton AK, Tillotson KM, Troup JDG. Prediction of lowback trouble frequency in a working population. Spine 1989;14,(9):939-46.

34. Leino P, Hasan J, Karppi SL. Occupational class, physical workload, and musculoskeletal morbidity in the engineering industry. Br J Ind Med 1988;45(10):672-81.

35. Rundcrantz BL, Johnsson B, Moritz U. Cervical pain and discomfort among dentists: epidemiological, clinical and therapeutic aspects, part 1: a survey of pain and discomfort. Swed Dent J 1990;14:71-80.

36. Saraste J, Hultman G. Life conditions of persons with and without low-back pain. Scand J Rehabil Med 1987;19:10913 .

37. Sobti A, Cooper C, Inskip H, Searle S, Coggon D. Occupational physical activity and long-term risk of musculoskeletal symptoms: a national survey of post office pensioners. Am J Ind Med 1997;32,(1):76-83.

38. Strasser PB, Lusk SL, Franzblau A, Armstrong TJ. Perceived psychological stress and upper extremity cumulative trauma disorders. AAOHN J 1999;47(1):22-30.

39. Vasseljen O, Westgaard RH, Larsen S. A case-control study of psychological and psychosocial risk factors for shoulder and neck pain at the workplace. Int Arch Occup Environ Health 1995;66(6):375-82.

40. Viikari-Juntura E, Martikainen R, Luukkonen R, Mutanen P, Takala EP, Riihimäki H. Longitudinal study on work related and individual risk factors affecting radiating neck pain. Occup Environ Med 2001;59(5):345-52.

41. Derriennic F, Iwatsubo Y, Monfort C, Cassou B. Evolution of osteoarticular disorders as a function of past heavy physical work factors: longitudinal analysis of 627 retired subjects living in the Paris area. Br J Ind Med 1993;50(9):851-60.

42. Räsänen K, Notkola V, Husman K. Perceived work conditions and work-related symptoms among employed Finns. Soc Sci Med 1997;45(7):1099-110.

43. Gorsche RG, Wiley JP, Renger RF, Brant RF, Gemer TY, Sasyniuk TM. Prevalence and incidence of carpal tunnel syndrome in a meat packing plant. Occup Environ Med 1999;56(6):417-22.

44. Blatter BM, Bongers PM. Duration of computer use and mouse use in relation to musculoskeletal disorders of neck or upper limb. Int J Ind Ergon 2002;30(4-5):295-306.

45. Feveille H, Jensen C, Burr H. Risk factors for neck-shoulder and wrist-hand symptoms in a 5-year follow up study of 3,990 employees in Denmark. Int Arch Occup Environ Health 2002; 75:243-51.

46. Xu Y, Bach E, Orhede E. Occupation and risk for the occurrence of low back pain (LBP) in Danish employees. Occup Med 1996;56(2):131-6.

47. Alcouffe J, Manillier P, Brehier M, Fabin C, Faupin F. Analysis by sex of low back pain among workers from small companies in the Paris area: severity and occupational consequences. Occup Environ Med 1999;56(10):696-701.

48. Cole DC, Ibrahim SA, Shannon HS, Scott F, Eyles J. Work correlates of back problems and activity restriction due to musculoskeletal disorders in the Canadian national population health survey (NPHS) 1994-5 data. Occup Environ Med 2001;58(11):728-34.

49. Foppa I, Noach RH. The relation of self-reported back pain to psychosocial, behavioural, and health-related factors in a working population in Switzerland. Soc Sci Med 1996;43(7):1119-26.

50. Heliövaara M. Occupation and risk of herniated lumbar intervertebral disc or sciatica leading to hospitalization. J Chronic Dis 1987;40(3):259-64.

51. Hemingway H, Shipley MJ, Stansfeld S, Marmot M. Sickness absence from back pain, psychosocial work characteristics and employment grade among office workers. Scand J Work Environ Health 1997;23(1):121-9.

52. Kelsey JL. An epidemiological study of acute herniated lumbar intervertebral discs. Rheumatol Rehabil 1975;14(3):14459.

53. Latza U, Kohlmann T, Deck R, Raspe H. Influence of occupational factors on the relation between socioeconomic status and self-reported back pain in a population-based sample of German adults with back pain. Spine 2000;25(11):1390-7.

54. Macfarlane GJ, Thomas E, Papageorgiou AC, Croft PR, Jayson MI, Silman AJ. Employment and physical work activities as predictors of future low back pain. Spine 1997;22(10):1143-9.

55. Matsui H, Maeda A, Tsuji H, Naruse Y. Risk indicators of low back pain among workers in Japan: association of familial and physical factors with low back pain. Spine 1997;22(11):1242-7.

56. Walsh K, Varnes N, Osmond C, Styles R, Coggon D. Occupational causes of low-back pain. Scand J Work Environ Health 1989;15(1):54-9.

57. Walsh K, Cruddas M, Coggon D. Interaction of height and mechanical loading of the spine in the development of lowback pain. Scand J Work Environ Health 1991;17(6):420-4.

58. Barnekow-Bergkvist M, Hedberg GE, Janlert U, Jansson E. Determinants of self-reported neck-shoulder and low back symptoms in a general population. Spine 1998;23(2):23543.

59. Bildt-Thorbjörnsson COB, Alfredsson L, Fredriksson K, Koster M, Michelsen H, Vingard E, et al. Psychosocial and physical risk factors associated with low back pain: a 24 year follow up among women and men in a broad range of occupations. Occup Environ Med 1998;55(3):84-90.

60. Vingard E, Alfredsson L, Hagberg M, Josephson M, Kilbom A, Theorell T, et al. Age and gender differences in exposure patterns and low back pain in the MUSIC-Norrtalje study. Am J Ind Med 1999; Suppl 1:26-8.

61. Cassou B, Derriennic F, Monfort C, Norton J, Touranchet A. Chronic neck and shoulder pain, age, and working conditions: longitudinal results from a large random sample in France. Occup Environ Med 2002;59(8):537-44.

62. Palmer KT, Walker-Bone K, Griffin MJ, Syddall H, Pannett $\mathrm{B}$, Coggon D, et al. Prevalence and occupational associations of neck pain in the British population. Scand J Work Environ Health 2001;27(1):49-56.

63. Pope DP, Croft PR, Pritchard CM, Silman AJ, Macfarlane GJ. Occupational factors related to shoulder pain and disability. Occup Environ Med 1997;54(5):316-21.

64. Mäkelä M, Heliövaara M, Sievers K, Impivaara $\mathrm{O}$, Knekt $\mathrm{P}$, Aromaa A. Prevalence, determinants, and consequences of chronic neck pain in Finland. Am $J$ Epidemiol 1991;134(11):1356-67.

65. Jensen C, Ryholt CU, Burr H, Villadsen E, Christensen H. Work related psychosocial, physical and individual factors associated with musculoskeletal symptoms in computer users. Work Stress 2002;16(2):107-20.

66. Karlqvist L, Tornqvist EW, Hagberg M, Hagman M, Toom- 
ingas A. Self reported working conditions of VDU operators and associations with musculoskeletal symptoms: a crossectional study focussing on gender differences. Int J Ind Ergon 2002;30:277-84.

67. Fransson-Hall C, Bystrom S, Kilbom A. Self-reported physical exposure and musculoskeletal symptoms of the forearmhand among automobile assembly-line workers. J Occup Environ Med 1995;37(9):1136-44.

68. Tanaka S, Wild DK, Seligman PJ, Halperin WE, Behrens VJ, Putz-Anderson V. Prevalence and work-relatedness of selfreported carpal tunnel syndrome among US workers: analysis of the Occupational Health Supplement data of 1988 National Health Interview Survey. Am J Ind Med 1995; 27(4):451-70.

69. Coggon D, Croft P, Kellingray S, Barrett D, McLaren M, Cooper C. Occupational physical activities and osteoarthritis of the knee. Arthritis Rheum 2000;43(7):1443-9.

70. Coggon D, Kellingray S, Inskip H, Croft P, Campbell L, Cooper C. Osteoarthritis of the hip and occupational lifting. Am J Epidemiol 1998;147(6):523-8.

71. Lau EC, Cooper C, Lam D, Chan VN, Tsang KK, Sham A. Factors associated with osteoarthritis of the hip and knee in Hong Kong Chinese: obesity, joint injury, and occupational activities. Am J Epidemiol 2000;152(9):855-62.

72. Manninen P, Heliovaara M, Riihimaki H, SuomaIainen O Physical workload and the risk of severe knee osteoarthritis. Scand J Work Environ Health 2002;28(1):25-32.

73. Marras WS, Davis KG, Jorgensen M. Gender influences on spine loads during complex lifting. Spine J 2003;3(2):93-9.

74. Marras WS, Davis KG, Jorgensen M. Spine loading as a function of gender. Spine 2002;27(22):2514-20.

75. Palmer KT, Griffin MJ, Bendall H, Pannett B, Coggon D. Prevalence and pattern of occupational exposure to hand transmitted vibration in Great Britain: findings from a national survey. Occup Environ Med 2000;57:218-28.

76. Ferreira PH, Ferreira ML, Maher CG, Refshauge K, Herbert $\mathrm{RD}$, Latimer J. Effect of applying different "levels of evidence" criteria on conclusions of Cochrane reviews of interventions for low back pain. J Clin Epidemiol 2002;55:11269 .

77. Colle F, Rannou F, Revel M, Fermaninan J, Poidraudeau S. Impact of quality scales on levels of evidence inferred from a systematic review of exercise therapy and low back pain. Arch Phys Med Rehabil 2002;83(12):1745-52.

78. West S, King V, Carey TS, Lohr KN, McKoy N, Sutton SF, et al. Systems to rate the strength of scientific evidence. Rockville (MD): Agency for Healthcare Research and Quality (AHRQ); 2002. AHRQ publication no 02-E016. Evidence report/technology assessment no 47.

79. Köster M, Alfredsson L, Michélsen H, Vingärd E, Kilbom Å. Retrospective versus original information on physical and psychosocial exposure at work. Scand J Work Environ Health 1999;25(5):410-4.

80. Fredriksson K, Alfredsson L, Thorbjörnsson CB, Punnett L, Toomingas A, Torgen M, et al. Risk factors for neck and shoulder disorders: a nested case-control study covering a 24-year period. Am J Ind Med 2000;38(5):516-28.

81. Fredriksson K, Alfredsson L, Koster M, Thorbjörnsson CB, Toomingas A, Torgen M, et al. Risk factors for neck and upper limb disorders: results from 24 years of follow up. Occup Environ Med 1999;56(1.):59-66.

82. Bildt-Thorbjörnsson COB, Alfredsson L, Fredriksson K, Michelsen H, Punnett L, Vingard E, et al. Physical and psychosocial factors related to low back pain during a 24 year period. Spine 2000;25(3):369-75.

83. Torgen M, Alfredsson L, Köster M, Wiktorin C, Smith K, Kilbom A. Reproducibility of a questionnaire for assessment of present and past physical activities. Int Arch Occup Environ Health 1997;70:107-18.

84. Bildt-Thorbjörnsson C, Michélsen H, Kilbom Å. Method for retrospective collection of work-related psychosocial risk factors for musculoskeletal disorders: reliability and aggregation. J Occup Health Psychol 1999;4(3):193-206.

85. Tornqvist EW, Kilbom A, Vingard E, Alfredsson L, Hagberg $\mathrm{M}$, Theorell $\mathrm{T}$, et al. The influence on seeking care because of neck and shoulder disorders from work-related exposures. Epidemiology 2001;12(5):537-45.

86. Vingard E, Alfredsson L, Hagberg M, Kilbom A, Theorell T, Waldenstrom M, et al. To what extent do current and past physical and psychosocial occupational factors explain careseeking for low back pain in a working population? results from the Musculoskeletal Intervention Center-Norrtalje Study. Spine 2000;25(4):493-500.

87. Wiktorin C, Selin K, Ekenvall L, Alfredsson L. An interview technique for recording work postures in epidemiological studies. Int J Epidemiol 1996;25(1):171-80.

88. Waldenstrom M, Josephson M, Persson C, Theorell T. Interview reliability for assessing mental work demands. J Occup Health Psychol 1998;3(3):209-16.

89. Wiktorin C, Hjelm EW, Winkel J, Köster M. Reproducibility of a questionnaire for assessment of physical load during work and leisure time. J Occup Environ Med 1996;38(2):190-201.

90. Wiktorin C, Vingård E, Mortimer M, Pernold G, WigaeusHjelm E, Kilbom $\AA$, et al. Interview versus questionnaire for assessing physical loads in the population-based MUSICNorrtälje study. Am J Ind Med 1999;35:441-55.

91. Torgén M, Winkel J, Alfredsson L, Kilbom Å, Stockholm MUSIC 1 Study Group. Evaluation of questionnaire-based information on previous physical work loads. Scand J Work Environ Health 1999;25(3):246-54.

92. Mortimer M, Wiktorin C, Pernold G, Vingård E. Interrater reliability of a physical examination of the low-back and the neck and shoulder. In: Proceedings of the 1998 PREMUSISEOH symposium. Helsinki: Finnish Institute of Occupational Health; 1998:61.

93. Mäkelä M, Heliövaara M, Sainio P, Knekt P, Impivaara O, Aromaa A. Shoulder joint impairment among Finns aged 30 years or over: prevalence, risk factors and co-morbidity. Rheumatology (Oxford) 1999;38(7):656-62.

94. Dollard MF, Winefield AH. A test of the demand-control/ support model of work stress in correctional officers. J Occup Health Psychol 1998;3(3):243-64.

95. Croft PR, Papageorgiou AC, Thomas E, Macfarlane GJ, Silman A J. Short-term physical risk factors for new episodes of low back pain: prospective evidence from the South Manchester Back Pain Study. Spine 1999;24(15):1556-61.

96. Papageorgiou AC, Macfarlane GJ, Thomas E, Croft PR, Jayson MI, Silman AJ. Psychosocial factors in the workplacedo they predict new episodes of low back pain? Spine 1997;22:1137-42.

97. Papageorgiou AC, Croft PR, Ferry S, Jayson MI, Silman AJ. Estimating the prevalence of low back pain in the general population. Spine 1995;20(17):1889-94.

98. Cooper C, McAlindon T, Coggon D, Egger P, Dieppe P. Occupational activity and osteoarthritis of the knee. Ann Rheum Dis 1994;53(2):90-3.

99. Jensen C, Finsen L, Sogaard K, Christensen H. Musculoskel- 
etal symptoms and duration of computer and mouse use. Int $\mathbf{J}$ Ind Ergon 2002;30:265-75.

100. Tanaka S, Petersen M, Cameron L. Prevalence and risk factors of tendinitis and related disorders of the distal upper extremity among US workers: comparison to carpal tunnel syndrome. Am J Ind Med 2001;39(3):328-35.

101. Tanaka S, Wild DK, Cameron LL, Freund E. Association of occupational and non-occupational risk factors with the prevalence of self-reported carpal tunnel syndrome in a national survey of the working population. Am J Ind Med 1997;32(5):550-6.
102. Michel A, Kohlmann T, Raspe H. The association between clinical findings on physical examination and self reported severity in back pain. Spine 1997;22(3):297-303.

103. Kelsey JL. An epidemiological study of the relationship between occupations and acute herniated lumbar intervertebral discs. Int J Epidemiol 1975;4(3):197-205.

104. Kelsey JL, Hardy RJ. Driving of motor vehicles as a risk factor for acute herniated lumbar intervertebral disc. Am J Epidemiol 1975;102(1):63-73.

Received for publication: 14 August 2003

\section{Appendix}

\section{Description of the studies included in the analyses}

Table 1. Description of the studies on back complaints. $(\mathrm{CC}=$ case-control, $\mathrm{CH}=$ cohort, $\mathrm{CS}=$ cross-sectional, $\mathrm{HLD}=$ herniated lumbar intevertebral disc, $M Q=$ methodological quality score, $\mathrm{OR}=$ odds ratio, $\mathrm{PR}=$ prevalence ratio, $\mathrm{RR}=$ relative risk, TWA MET $=$ timeweighted average of the metabolic rate, $95 \% \mathrm{Cl}=95 \%$ confidence interval)

\begin{tabular}{|c|c|c|c|c|c|c|c|c|c|c|}
\hline \multirow[t]{3}{*}{ Study a } & \multirow{3}{*}{$\begin{array}{l}\text { De- } \\
\text { sign }\end{array}$} & \multirow{3}{*}{$\begin{array}{l}M Q \\
(\%)\end{array}$} & \multirow{3}{*}{ Population } & \multirow[t]{3}{*}{ Outcome } & \multirow[t]{3}{*}{ Exposure } & \multicolumn{4}{|c|}{ Association } & \multirow{3}{*}{$\begin{array}{l}\text { Gender } \\
\text { ratio }^{\text {b }}\end{array}$} \\
\hline & & & & & & \multicolumn{2}{|c|}{ Female } & \multicolumn{2}{|c|}{ Male } & \\
\hline & & & & & & $\begin{array}{l}\mathrm{OR}, \mathrm{RR} \\
\text { or PR }\end{array}$ & $95 \% \mathrm{Cl}$ & $\begin{array}{l}\mathrm{OR}, \mathrm{RR} \\
\text { or PR }\end{array}$ & $95 \% \mathrm{Cl}$ & \\
\hline $\begin{array}{l}\text { Bildt-Thorbjörnsson } \\
\text { et al, } 1998 \text { (59); } \\
\text { Köster et al, 1999 } \\
\text { (79); Bildt-Thorbjörns- } \\
\text { son et al, } 1999 \text { (84) }\end{array}$ & $\mathrm{CH}$ & 81 & $\begin{array}{l}\text { Working persons } \\
18-34 \text { years of } \\
\text { age }(N=2579)\end{array}$ & $\begin{array}{l}\text { Low-back pain in } \\
\text { previous } \\
12 \text { months }\end{array}$ & $\begin{array}{l}\text { High mental load } \\
\text { High physical load } \\
\text { Monotonous work } \\
\text { Overtime work } \\
\text { Poor social support }\end{array}$ & $\begin{array}{l}\text { PR } 1.1 \\
\text { PR } 1.0 \\
\text { PR } 0.9 \\
\text { PR } 1.0 \\
\text { PR } 1.2\end{array}$ & $\begin{array}{l}0.7-1.8 \\
0.9-1.5 \\
0.5-1.5 \\
0.7-2.1 \\
0.8-1.9\end{array}$ & $\begin{array}{l}\text { PR } 1.1 \\
\text { PR } 1.1 \\
\text { PR } 1.5 \\
\text { PR } 0.6 \\
\text { PR } 1.1\end{array}$ & $\begin{array}{l}0.6-1.8 \\
0.8-1.6 \\
0.9-2.4 \\
0.3-1.3 \\
0.6-1.8\end{array}$ & $\begin{array}{l}1.00 \\
0.91 \\
0.60 \\
1.67 \\
1.09\end{array}$ \\
\hline \multirow{8}{*}{$\begin{array}{l}\text { Hemingway et al, } \\
1997 \text { (51) }\end{array}$} & \multirow[t]{8}{*}{$\mathrm{CH}$} & \multirow[t]{8}{*}{56} & \multirow{8}{*}{$\begin{array}{l}\text { Nonindustrial } \\
\text { civil servants } \\
35-55 \text { years of } \\
\text { age }(N=6894 \\
\text { men, } N=3414 \\
\text { women) }\end{array}$} & \multirow{8}{*}{$\begin{array}{l}\text { Sickness ab- } \\
\text { sence }<7 \text { days } \\
\text { due to back pain }\end{array}$} & \multirow{8}{*}{$\begin{array}{l}\text { Job satisfaction } \\
\text { (low versus high) } \\
\text { Job satisfaction } \\
\text { (medium versus high) } \\
\text { Social support } \\
\text { (low versus high) } \\
\text { Social support } \\
\text { (medium versus high) } \\
\text { Work control } \\
\text { (low versus high) } \\
\text { Work control } \\
\text { (medium versus high) } \\
\text { Workpace } \\
\text { (medium versus high) } \\
\text { Workpace } \\
\text { (low versus high) }\end{array}$} & RR 1.15 & $0.83-1.58$ & RR 1.17 & $0.92-1.48$ & 0.98 \\
\hline & & & & & & RR 1.08 & $0.78-1.5$ & RR 1.04 & $0.8-1.33$ & 1.04 \\
\hline & & & & & & RR 0.87 & $0.63-1.19$ & RR 1.12 & $0.89-1.41$ & 0.78 \\
\hline & & & & & & RR 0.81 & $0.58-1.14$ & RR 1.01 & $0.8-1.27$ & 0.80 \\
\hline & & & & & & RR 1.01 & $0.7-1.47$ & RR 1.44 & $1.11-1.85$ & 0.70 \\
\hline & & & & & & RR 1.04 & $0.71-1.53$ & RR 1.31 & $1.04-1.64$ & 0.79 \\
\hline & & & & & & RR 1.5 & $1.05-2.15$ & RR 1.21 & $0.96-1.54$ & 1.24 \\
\hline & & & & & & RR 1.42 & $0.98-2.07$ & RR 1.79 & $1.39-2.31$ & 0.79 \\
\hline \multirow[t]{4}{*}{$\begin{array}{l}\text { Barnekow-Bergkvist } \\
\text { et al, } 1998 \text { (58) }\end{array}$} & \multirow[t]{4}{*}{$\mathrm{CH}$} & \multirow[t]{4}{*}{50} & \multirow[t]{4}{*}{$\begin{array}{l}\text { Students } 16 \\
\text { years of age at } \\
\text { baseline }(N=220 \\
\text { men, } N=205 \\
\text { women) }\end{array}$} & \multirow[t]{4}{*}{$\begin{array}{l}\text { Back symptoms } \\
\text { in previous } \\
12 \text { months }\end{array}$} & \multirow{4}{*}{$\begin{array}{l}\text { High decision latitude } \\
\text { High demand index } \\
\text { High job satisfaction } \\
\text { Lift index } \\
\text { (heavy) } \\
\text { Posture work index } \\
\text { (monotonous) } \\
\text { Social support index } \\
\text { (high) } \\
\text { Vibration }\end{array}$} & $\begin{array}{l}\text { OR } 1.35 \\
\text { OR } 1.2 \\
\text { OR } 0.95 \\
\text { OR } 0.17\end{array}$ & $\begin{array}{l}0.34-5.39 \\
0.31-4.71 \\
0.37-2.32 \\
0.02-1.37\end{array}$ & $\begin{array}{l}\text { OR } 1.00 \\
\text { OR } 0.63 \\
\text { OR } 0.83 \\
\text { OR } 0.94\end{array}$ & $\begin{array}{l}0.22-4.48 \\
0.18-2.13 \\
0.37-1.99 \\
0.24-3.6\end{array}$ & $\begin{array}{l}1.35 \\
1.90 \\
1.14 \\
0.18\end{array}$ \\
\hline & & & & & & OR 6.39 & $1.25-32.7$ & OR 5.45 & $1.07-27.9$ & 1.17 \\
\hline & & & & & & OR 1.91 & $0.47-7.78$ & 1.35 & $0.38-4.74$ & 1.41 \\
\hline & & & & & & OR 1.90 & $0.47-7.69$ & OR 3.29 & $1.34-8.08$ & 0.58 \\
\hline \multirow{3}{*}{$\begin{array}{l}\text { Macfarlane et al, } 1997 \\
\text { (54); Croft et al, } 1999 \\
\text { (95); Papageorgiou et } \\
\text { al, 1997 (96); Papage- } \\
\text { orgiou et al } 1995 \text { (97) }\end{array}$} & \multirow[t]{3}{*}{$\mathrm{CH}$} & \multirow[t]{3}{*}{44} & \multirow{3}{*}{$\begin{array}{l}\text { Adults with } 2 \\
\text { general practices } \\
(N=1884 \text { men, } \\
N=2617 \text { women) }\end{array}$} & \multirow{3}{*}{$\begin{array}{l}\text { Low-back pain, } \\
\text { no consultation } \\
\text { with general } \\
\text { practitioners }\end{array}$} & \multirow{3}{*}{$\begin{array}{l}\text { Driving a car in current } \\
\text { or previous job } \\
\text { Driving a truck in current } \\
\text { or previous job } \\
\text { Lift }>/ 25 \text { lbs }^{c}\end{array}$} & OR 1.4 & $0.3-5.9$ & OR 1.3 & $0.7-2.4$ & 1.08 \\
\hline & & & & & & OR 0 & & OR 1.2 & $0.5-3.1$ & 0.00 \\
\hline & & & & & & OR 2.5 & $1.5-4.1$ & OR 1.1 & $0.7-1.7$ & 2.27 \\
\hline
\end{tabular}


Table 1. Continued.

\begin{tabular}{|c|c|c|c|c|c|c|c|c|c|c|}
\hline \multirow[t]{3}{*}{ Study a } & \multirow{3}{*}{$\begin{array}{l}\text { De- } \\
\text { sign }\end{array}$} & \multirow{3}{*}{$\begin{array}{l}\text { MQ } \\
(\%)\end{array}$} & \multirow{3}{*}{ Population } & \multirow[t]{3}{*}{ Outcome } & \multirow[t]{3}{*}{ Exposure } & \multicolumn{4}{|c|}{ Association } & \multirow{3}{*}{$\begin{array}{l}\text { Gender } \\
\text { ratio }^{\mathrm{b}}\end{array}$} \\
\hline & & & & & & \multicolumn{2}{|c|}{ Female } & \multicolumn{2}{|c|}{ Male } & \\
\hline & & & & & & $\begin{array}{l}\text { OR, RR } \\
\text { or PR }\end{array}$ & $95 \% \mathrm{Cl}$ & $\begin{array}{l}\text { OR, RR } \\
\text { or PR }\end{array}$ & $95 \% \mathrm{Cl}$ & \\
\hline $\begin{array}{l}\text { Vingart et al, } 1999 \text { (60); } \\
\text { Tornqvist et al, 2001, } \\
\text { (85); Vingard et al, } 2000 \\
\text { (86); Wiktorin et al, } \\
1996 \text { (97, 89); Walde- } \\
\text { strom et al, } 1998 \text { (88); } \\
\text { Wiktorin et al, } 1999 \\
\text { (90); Torgén et al, } \\
\text { 1999 (91); Mortimer et } \\
\text { al, } 1998 \text { (92)(91); Mor- } \\
\text { timer et al, 1998 (92) }\end{array}$ & $\begin{array}{l}\mathrm{CC} \\
\\
- \\
-\end{array}$ & 78 & $\begin{array}{l}\text { Persons } 20-59 \\
\text { years of age } \\
\text { (cases: } N=315 \\
\text { men, } N=380 \text { wo- } \\
\text { men, controls: } \\
N=610 \text { men, } \\
N=813 \text { women) }\end{array}$ & $\begin{array}{l}\text { Seeking treat- } \\
\text { ment for low- } \\
\text { back pain }\end{array}$ & $\begin{array}{l}\text { Bend }>60 \text { minutes/day } \\
\text { Drive }>240 \text { minutes/day } \\
\text { Heavy lifting } \\
\text { Low influence over work } \\
\text { Manual materials handling } \\
\text { Medium influence over work } \\
\text { No social support at work } \\
\text { Poor job satisfaction } \\
\text { TWA MET >3.0 } \\
\text { TWA MET >3.5 }\end{array}$ & $\begin{array}{l}\text { RR } 1.2 \\
\text { RR } 2.8 \\
\text { RR } 0.8 \\
\text { RR } 1.0 \\
\text { RR } 1.2 \\
\text { RR } 1.2 \\
\text { RR } 0.9 \\
\text { RR } 0.7 \\
\text { RR } 1.9 \\
\text { RR } 1.5\end{array}$ & $\begin{array}{l}0.7-1.8 \\
1.8-8.5 \\
0.6-1.2 \\
0.7-1.5 \\
0.7-2 \\
0.9-1.6 \\
0.6-1.3 \\
0.3-1.7 \\
1.2-2.8 \\
1.4-4.6\end{array}$ & $\begin{array}{l}\text { RR } 1.8 \\
\text { RR } 0.9 \\
\text { RR } 1.4 \\
\text { RR } 1.0 \\
\text { RR } 1.5 \\
\text { RR } 1.6 \\
\text { RR } 1.0 \\
\text { RR } 2.1 \\
\text { RR } 1.4 \\
\text { RR } 1.1\end{array}$ & $\begin{array}{l}1.1-3.1 \\
0.6-1.5 \\
1.0-2.0 \\
0.6-1.6 \\
0.8-2.9 \\
1.2-2.2 \\
0.7-1.4 \\
0.9-5.2 \\
1.0-2.0 \\
0.8-1.7\end{array}$ & $\begin{array}{l}0.67 \\
3.11 \\
0.57 \\
1.00 \\
0.80 \\
0.75 \\
0.90 \\
0.33 \\
1.36 \\
1.36\end{array}$ \\
\hline \multirow[t]{3}{*}{ Heliövaara, 1987 (50) } & \multirow[t]{3}{*}{$\mathrm{CC}$} & \multirow[t]{3}{*}{44} & $\begin{array}{l}\text { Persons dis- } \\
\text { charged from } \\
\text { hospital due to } \\
\text { HLD (cases: N=212 } \\
\text { men, } N=124 \\
\text { women; controls: } \\
N=767 \text { men, } \\
N=454 \text { women) }\end{array}$ & HLD & $\begin{array}{l}\text { Work strenuousness } \\
\text { (heavy versus light) } \\
\text { Work strenuousness } \\
\text { (normal versus light) }\end{array}$ & \multicolumn{2}{|l|}{ RR 3.8} & \multicolumn{2}{|l|}{ RR 0.7} & $\begin{array}{l}3.43 \\
5.43\end{array}$ \\
\hline & & & \multirow{2}{*}{\multicolumn{2}{|c|}{$\begin{array}{l}\text { Persons discharg- HLD or sciata } \\
\text { ed from hospital } \\
\text { due to sciatica (ca- } \\
\text { ses: } N=364 \text { men, } \\
N=228 \text { women; } \\
\text { controls } N=1298 \\
\text { men, } 842 \text { women) }\end{array}$}} & $\begin{array}{l}\text { Work strenuousness } \\
\text { (heavy versus light) }\end{array}$ & \multicolumn{2}{|l|}{ RR 2.5} & \multicolumn{2}{|l|}{ RR 1.1} & 2.27 \\
\hline & & & & & $\begin{array}{l}\text { Work strenuousness } \\
\text { (normal versus light) }\end{array}$ & \multicolumn{2}{|l|}{ RR 2.0} & \multicolumn{2}{|l|}{ RR 0.9} & 2.22 \\
\hline $\begin{array}{l}\text { Kelsey, } 1975 \text { (52, } \\
103) ; \text { Kelsey \& Hardy, } \\
1975 \text { (104) }\end{array}$ & $\mathrm{CC}$ & 28 & $\begin{array}{l}\text { Persons 20-64 } \\
\text { years of age }\end{array}$ & HLD & $\begin{array}{l}\text { Driving a car } \\
\text { Lifting }\end{array}$ & $\begin{array}{l}\text { OR } 1.92 \\
\text { RR } 1.73\end{array}$ & $1.18-3.11$ & $\begin{array}{l}\text { OR } 2.46 \\
\text { RR } 1.17\end{array}$ & $1.03-5.87$ & $\begin{array}{l}0.78 \\
1.48\end{array}$ \\
\hline \multirow{4}{*}{$\begin{array}{l}\text { Cole et al, } 2001 \text { (48); } \\
\text { Dollard \& Winefield, } \\
1998 \text { (94) }\end{array}$} & \multirow[t]{4}{*}{ CS } & \multirow[t]{4}{*}{57} & \multirow{4}{*}{$\begin{array}{l}\text { Persons } 18-64 \\
\text { years of age } \\
(\mathrm{N}=4230 \text { men, } \\
\mathrm{N}=4043 \text { women })\end{array}$} & \multirow{4}{*}{$\begin{array}{l}\text { Back problems } \\
\text { (excluding arthri- } \\
\text { tis) expected to } \\
\text { last }>6 \text { months }\end{array}$} & $\begin{array}{l}\text { Decision latitude (high } \\
\text { versus low) }\end{array}$ & RR 1.00 & $0.77-1.29$ & RR 0.87 & $0.69-1.11$ & 1.15 \\
\hline & & & & & $\begin{array}{l}\text { Psychological demands } \\
\text { (high versus low) }\end{array}$ & RR 1.63 & $1.26-2.1$ & RR 1.21 & $0.96-1.53$ & 1.35 \\
\hline & & & & & $\begin{array}{l}\text { Work physical exertion } \\
\text { (high versus low) }\end{array}$ & RR 1.58 & $1.08-2.3$ & RR 1.37 & $1.1-1.72$ & 1.15 \\
\hline & & & & & $\begin{array}{l}\text { Work social support } \\
\text { (high versus low) }\end{array}$ & RR 1.08 & $0.85-1.38$ & RR 1.21 & $0.96-1.51$ & 0.89 \\
\hline \multirow[t]{4}{*}{$\begin{array}{l}\text { Alcouffe et al, } 1999 \\
\text { (47) }\end{array}$} & CS & 50 & $\begin{array}{l}\text { Random sample } \\
\text { of workers } \\
\text { ( } N=1342 \text { men, }\end{array}$ & $\begin{array}{l}\text { Low-back pain in } \\
\text { the previous } \\
\text { month }\end{array}$ & $\begin{array}{l}\text { Manual lifting } 10 \mathrm{~kg} \text { every day } \\
\text { Manual lifting } 10 \mathrm{~kg}<1 \text { time } \\
\text { per week }\end{array}$ & $\begin{array}{l}\text { OR } 1.69 \\
\text { OR } 1.35\end{array}$ & $\begin{array}{l}1.27-2.25 \\
1.04-1.75\end{array}$ & $\begin{array}{l}\text { OR } 1.27 \\
\text { OR } 1.23\end{array}$ & $\begin{array}{l}1.06-1.53 \\
1.01-1.53\end{array}$ & $\begin{array}{l}1.33 \\
1.10\end{array}$ \\
\hline & & & $\mathrm{N}=3168$ women) & & $\begin{array}{l}\text { Manual lifting } 10 \mathrm{~kg} \geq 1 \text { time } \\
\text { per week }\end{array}$ & OR 1.62 & $1.25-2.1$ & OR 1.20 & $10.1-1.44$ & 1.35 \\
\hline & & & & & $\begin{array}{l}\text { No means to achieve good } \\
\text { quality work }\end{array}$ & OR 1.38 & $1.15-1.65$ & OR 1.39 & $1.19-1.63$ & 0.99 \\
\hline & & & & & $\begin{array}{l}\text { No uncomfortable work } \\
\text { postures }\end{array}$ & OR 0.49 & $0.41-0.59$ & OR 0.54 & $0.46-1.6$ & 0.91 \\
\hline Walsh et al, 1989 (56) & CS & 50 & $\begin{array}{l}\text { Persons } 20-70 \\
\text { years of age }\end{array}$ & $\begin{array}{l}\text { Low-back pain } \\
\text { ever }\end{array}$ & $\begin{array}{l}\text { Driving car or van }>4 \text { hours } \\
\text { (at birthday prior to onset) }\end{array}$ & RR 0.4 & $0.1-3.2$ & RR 1.7 & $1-2.9$ & 0.24 \\
\hline & & & $(N=436)$ & & & RR 0.8 & $0.1-7.1$ & RR 1.2 & $0.5-2.8$ & 0.67 \\
\hline & & & & & $\begin{array}{l}\text { Driving truck, tractor or digger } \\
\text { (at birthday prior to onset) }\end{array}$ & RR 0.6 & $0.1-5.2$ & RR 0.7 & $0.4-1.4$ & 0.86 \\
\hline & & & & & $\begin{array}{l}\text { Driving truck, tractor or } \\
\text { digger (lifetime) }\end{array}$ & RR 1.6 & $0.1-16.6$ & RR 0.5 & $0.2-1$ & 3.20 \\
\hline & & & & & $\begin{array}{l}\text { Lifting or moving }>25 \mathrm{~kg} \text { by } \\
\text { hand (at birthday prior to onset) }\end{array}$ & RR 2.0 & $1.1-3.7$ & RR 2.0 & $1.3-3.1$ & 1.00 \\
\hline & & & & & & RR 1.1 & $0.5-2.4$ & RR 1.5 & $1.0-2.4$ & 0.73 \\
\hline & & & & & $\begin{array}{l}\text { Using vibrating machinery } \\
\text { (at birthday prior to onset) }\end{array}$ & RR 1.1 & $0.1-9.4$ & RR 1.3 & $0.7-2.4$ & 0.85 \\
\hline & & & & & $\begin{array}{l}\text { Using vibrating machinery } \\
\text { (lifetime) }\end{array}$ & RR 5.7 & $1.1-29.3$ & RR 1.5 & $0.7-3.1$ & 3.80 \\
\hline $\begin{array}{l}\text { Foppa \& Noach, } \\
1996(49)\end{array}$ & CS & 43 & $\begin{array}{l}\text { Workers }(\mathrm{N}=623 \\
\text { men, } \mathrm{N}=227 \\
\text { women) }\end{array}$ & $\begin{array}{l}\text { Severe-moderate } \\
\text { back pain during } \\
\text { previous } 4 \\
\text { months }\end{array}$ & $\begin{array}{l}\text { High responsibility } \\
\text { Job demands } \\
\text { Low job satisfaction } \\
\text { Physically demanding job } \\
\text { Subjective workload } \\
\text { Time pressure }\end{array}$ & $\begin{array}{l}\text { RR } 0.87 \\
\text { RR } 1.56 \\
\text { RR } 1.16 \\
\text { RR } 1.37 \\
\text { RR } 1.39 \\
\text { RR } 1.39\end{array}$ & $\begin{array}{l}0.43-1.78 \\
1.16-2.09 \\
0.85-1.58 \\
1.02-1.84 \\
1.04-1.88 \\
1.02-1.9\end{array}$ & $\begin{array}{l}\text { RR } 0.99 \\
\text { RR } 1.63 \\
\text { RR } 1.40 \\
\text { RR } 1.37 \\
\text { RR } 1.36 \\
\text { RR } 0.90\end{array}$ & $\begin{array}{l}0.78-1.26 \\
1.23-2.06 \\
1.1-1.77 \\
1.08-1.74 \\
1.07-1.73 \\
0.7-1.15\end{array}$ & $\begin{array}{l}0.88 \\
0.96 \\
0.83 \\
1.00 \\
1.02 \\
1.54\end{array}$ \\
\hline
\end{tabular}


Table 1. Continued.

\begin{tabular}{|c|c|c|c|c|c|c|c|c|c|c|}
\hline \multirow[t]{3}{*}{ Study a } & \multirow{3}{*}{$\begin{array}{l}\text { De- } \\
\text { sign }\end{array}$} & \multirow{3}{*}{$\begin{array}{l}M Q \\
(\%)\end{array}$} & \multirow{3}{*}{ Population } & \multirow[t]{3}{*}{ Outcome } & \multirow[t]{3}{*}{ Exposure } & \multicolumn{4}{|c|}{ Association } & \multirow{3}{*}{$\begin{array}{r}\text { Gender } \\
\text { ratio }^{\mathrm{b}}\end{array}$} \\
\hline & & & & & & \multicolumn{2}{|c|}{ Female } & \multicolumn{2}{|c|}{ Male } & \\
\hline & & & & & & $\begin{array}{l}\text { OR, RR } \\
\text { or PR }\end{array}$ & $95 \% \mathrm{Cl}$ & $\begin{array}{l}\text { OR, RR } \\
\text { or PR }\end{array}$ & $95 \% \mathrm{Cl}$ & \\
\hline \multirow{4}{*}{$\begin{array}{l}\text { Walsh et al, } \\
1991 \text { (57) }\end{array}$} & \multirow[t]{4}{*}{ CS } & \multirow[t]{4}{*}{43} & \multirow{4}{*}{$\begin{array}{l}\text { Persons from } \\
\text { general practi- } \\
\text { tioners offices } \\
(\mathrm{N}=1172 \text { men, } \\
\mathrm{N}=1495 \text { women })\end{array}$} & \multirow{4}{*}{$\begin{array}{l}\text { Low-back pain } \\
\text { lasting }>1 \text { day }\end{array}$} & \multirow{4}{*}{$\begin{array}{l}\text { Driving car or van }>4 \text { hours } \\
\text { (at birthday prior to onset) } \\
\text { Driving truck, tractor or digger } \\
\text { (at birthday prior to onset) } \\
\text { Lifting or moving }>25 \mathrm{~kg} \text { by } \\
\text { hand at birthday prior to onset } \\
\text { Using vibrating machinery } \\
\text { at birthday prior to onset }\end{array}$} & RR 1.4 & $0.2-8.2$ & RR 1.0 & $0.6-1.8$ & 1.40 \\
\hline & & & & & & RR 4.5 & $0.3-65$ & RR .1 & $0.7-1.7$ & 4.09 \\
\hline & & & & & & RR 2.2 & $1.3-3.5$ & RR 2.0 & $1.4-2.8$ & 1.10 \\
\hline & & & & & & RR 2.7 & $0.6-12.8$ & RR 0.8 & $0.5-1.3$ & 3.38 \\
\hline \multirow{3}{*}{$\begin{array}{l}\text { Matsui et al, } \\
1997(55)\end{array}$} & \multirow[t]{3}{*}{ CS } & \multirow[t]{3}{*}{36} & \multirow{3}{*}{$\begin{array}{l}\text { Workers of a } \\
\text { manufacturing } \\
\text { company }(\mathrm{N}=517 \\
\text { men, } \mathrm{N}=525 \\
\text { women) }\end{array}$} & \multirow{2}{*}{$\begin{array}{l}\text { Low-back pain at } \\
\text { time of inter- } \\
\text { view }\end{array}$} & \multirow{3}{*}{$\begin{array}{l}\text { Physical work demands } \\
\text { (light versus sedentary) } \\
\text { Physical work demands } \\
\text { (moderate versus sedentary) } \\
\text { r Heavy physical work demands }\end{array}$} & RR 1.2 & $0.4-3.4$ & RR 1.5 & $1.1-1.9$ & 0.80 \\
\hline & & & & & & RR 3.5 & $1.1-10.8$ & RR 3.2 & $1.9-5.2$ & 1.09 \\
\hline & & & & Low -back pain ever & & RR 1.38 & $1.09-1.74$ & RR 0.68 & $0.6-0.78$ & 2.03 \\
\hline \multirow{4}{*}{$\begin{array}{l}\text { Latza et al, } 2000 \\
\text { (53); Michel et al, } \\
1997 \text { (102) }\end{array}$} & \multirow[t]{4}{*}{ CS } & \multirow[t]{4}{*}{29} & \multirow{4}{*}{$\begin{array}{l}\text { Persons from } \\
\text { the general } \\
\text { population } 25- \\
74 \text { years of age } \\
(\mathrm{N}=459)\end{array}$} & \multirow{4}{*}{$\begin{array}{l}\text { Low-back pain, } \\
\text { grade II/III } \\
\text { Unremitting low- } \\
\text { back pain }\end{array}$} & Working in bent position & RR 0.75 & $0.41-1.37$ & RR 1.89 & $1.03-3.46$ & 0.40 \\
\hline & & & & & $\begin{array}{l}\text { Driving truck, tractor or } \\
\text { digger (lifetime) }\end{array}$ & RR 1.1 & $0.1-13.2$ & RR 1.4 & $0.4-5.1$ & 0.79 \\
\hline & & & & & $\begin{array}{l}\text { Lifting or moving }>25 \mathrm{~kg} \text { by } \\
\text { hand (lifetime) }\end{array}$ & RR 2.9 & $0.8-10.2$ & RR 5.3 & $1.3-20.9$ & 0.55 \\
\hline & & & & & $\begin{array}{l}\text { Using vibrating machinery } \\
\text { (lifetime) }\end{array}$ & RR 3.3 & $0.3-41$ & RR 1.3 & $0.3-5.3$ & 2.54 \\
\hline
\end{tabular}

a For references see the general reference list of the review.

${ }^{b}$ Ratio of the risk of women to the risk of men (female/male).

c $1 \mathrm{lbs}=0.4536 \mathrm{~kg}$.

Table 2. Description of the studies on neck-shoulder complaints. (CC = case-control, $\mathrm{CH}=$ cohort, $\mathrm{CS}=$ cross-sectional, $\mathrm{OR}=0 \mathrm{dds}$ ratio, $\mathrm{PR}=$ prevalence ratio, $\mathrm{RR}=$ relative risk, $95 \% \mathrm{Cl}=95 \%$ confidence interval)

\begin{tabular}{|c|c|c|c|c|c|c|c|c|c|c|}
\hline \multirow[t]{3}{*}{ Study a } & \multirow{3}{*}{$\begin{array}{l}\text { De- } \\
\text { sign }\end{array}$} & \multirow{3}{*}{$\begin{array}{l}\mathrm{MQ} P \\
(\%)\end{array}$} & \multirow{3}{*}{ Population } & \multirow[t]{3}{*}{ Outcome } & \multirow[t]{3}{*}{ Exposure } & \multicolumn{4}{|c|}{ Association } & \multirow{3}{*}{$\begin{array}{l}\text { Gender } \\
\text { ratio }^{\mathrm{b}}\end{array}$} \\
\hline & & & & & & \multicolumn{2}{|c|}{ Female } & \multicolumn{2}{|c|}{ Male } & \\
\hline & & & & & & $\begin{array}{l}\text { OR, RR } \\
\text { or PR }\end{array}$ & $95 \% \mathrm{Cl}$ & $\begin{array}{l}\text { OR, RR } \\
\text { or PR }\end{array}$ & $95 \% \mathrm{Cl}$ & \\
\hline \multirow{3}{*}{\multicolumn{2}{|c|}{$\begin{array}{l}\text { Bildt-Thorbjörnsson } \\
\text { et al, } 1998 \text { (59); Kös- } \\
\text { ter et al, 1999 (79), } \\
\text { Fredriksson et al, } 2000 \\
\text { (80); Fredriksson et al, } \\
1999 \text { (81); Thorbjörns- } \\
\text { son et al, 2000 (82); } \\
\text { Torgen et al, } 1997 \text { (83); } \\
\text { Bildt-Thorbjörnsson et } \\
\text { al, } 1999 \text { (84) }\end{array}$}} & \multirow[t]{3}{*}{$\begin{array}{l}81 \\
72\end{array}$} & \multirow[t]{3}{*}{$\begin{array}{l}\text { Working people } \\
18-34 \text { years of } \\
\text { age }(N=2579)\end{array}$} & \multirow{3}{*}{$\begin{array}{l}\text { Consultation } \\
\text { with physician, } \\
\text { symptom or sick } \\
\text { leave for neck, } \\
\text { shoulder or neck } \\
\text { and shoulder }\end{array}$} & \multirow{3}{*}{$\begin{array}{l}\text { High mental load at work } \\
\text { High mental load } \\
\text { Frequent hand or finger } \\
\text { movement } \\
\text { Handheld vibrating tools } \\
\text { High perceived workload } \\
\text { Influence over work index } \\
\text { (low) } \\
\text { Time pressure }\end{array}$} & $\begin{array}{l}\text { PR } 1.1 \\
\text { PR } 1.2 \\
\text { PR } 1.5\end{array}$ & $\begin{array}{l}0.2-4.9 \\
0.3-4.4 \\
1.0-2.3\end{array}$ & $\begin{array}{l}\text { PR } 1.5 \\
\text { PR } 1.7 \\
\text { PR } 1.6\end{array}$ & $\begin{array}{l}0.5-5.1 \\
0.6-4.9 \\
0.9-2.8\end{array}$ & $\begin{array}{l}0.73 \\
0.71 \\
0.94\end{array}$ \\
\hline & & & & & & $\begin{array}{l}\text { PR } 0.7 \\
\text { PR } 1.6 \\
\text { PR } 1.2\end{array}$ & $\begin{array}{l}0.2-2.4 \\
0.9-2.6 \\
0.7-1.9\end{array}$ & $\begin{array}{l}\text { PR } 1.3 \\
\text { PR } 0.9 \\
\text { PR } 0.9\end{array}$ & $\begin{array}{l}0.7-2.1 \\
0.4-1.8 \\
0.5-1.7\end{array}$ & $\begin{array}{l}0.54 \\
1.78 \\
1.33\end{array}$ \\
\hline & & & & & & PR 0.9 & $0.5-1.8$ & PR 0.3 & $0.1-1.0$ & 3.00 \\
\hline \multirow{3}{*}{\multicolumn{2}{|c|}{ Cassou et al, $2002(61) \mathrm{Cr}$}} & \multirow[t]{3}{*}{63} & \multirow{3}{*}{$\begin{array}{l}\text { Random selec- } \\
\text { tion of workers } \\
\text { ( } N=9787 \text { men, } \\
N=7163 \text { women })\end{array}$} & \multirow{3}{*}{$\begin{array}{l}\text { Chronic neck and } \\
\text { shoulder pain }\end{array}$} & \multirow{3}{*}{$\begin{array}{l}\text { Repetitive work under time } \\
\text { constraints at baseline } \\
\text { Repetitive work under time } \\
\text { constraints before baseline } \\
\text { High job demands }\end{array}$} & OR 1.3 & $1.0-1.6$ & OR 0.9 & $0.7-1.2$ & 1.44 \\
\hline & & & & & & OR 1.2 & $1.0-1.5$ & OR 1.3 & $1.0-1.7$ & 0.92 \\
\hline & & & & & & OR 1.2 & $1.0-1.4$ & OR 1.2 & $1.0-1.4$ & 1.00 \\
\hline \multirow[t]{2}{*}{$\begin{array}{l}\text { Barnekow-Bergkvist } \\
\text { et al, } 1998 \text { (58) }\end{array}$} & \multirow[t]{2}{*}{$\mathrm{CH}$} & \multirow[t]{2}{*}{50} & \multirow[t]{2}{*}{$\begin{array}{l}\text { Students } 16 \\
\text { years of age at } \\
\text { baseline }(N=220 \\
\text { males, } N=205 \\
\text { females })\end{array}$} & \multirow[t]{2}{*}{$\begin{array}{l}\text { Neck-shoulder } \\
\text { symptoms } \\
\text { in previous } \\
12 \text { months }\end{array}$} & \multirow[t]{2}{*}{$\begin{array}{l}\text { Decision latitude (high) } \\
\text { Demand index (high) } \\
\text { Lift index (heavy) } \\
\text { Posture work index } \\
\text { (monotonous) } \\
\text { Social support index (high) }\end{array}$} & $\begin{array}{l}\text { OR } 3.80 \\
\text { OR } 0.49 \\
\text { OR } 0.20 \\
\text { OR } 5.88\end{array}$ & $\begin{array}{l}1.00-14.4 \\
0.13-1.84 \\
0.05-0.85 \\
1.52-22.8\end{array}$ & $\begin{array}{l}\text { OR } 0.76 \\
\text { OR } 0.76 \\
\text { OR } 0.26 \\
\text { OR } 0.92\end{array}$ & $\begin{array}{l}0.22-2.57 \\
0.23-2.48 \\
0.08-0.87 \\
0.29-2.94\end{array}$ & $\begin{array}{l}5.00 \\
0.64 \\
0.77 \\
6.39\end{array}$ \\
\hline & & & & & & OR 0.91 & $0.27-3.07$ & OR 1.11 & $0.39-3.22$ & 0.82 \\
\hline \multirow{3}{*}{$\begin{array}{l}\text { Vingard et al, } 1999 \\
\text { (60); Tornqvist et al, } \\
\text { 2001 (85); Vingard et } \\
\text { al, } 2000 \text { (86); Wiktorin } \\
\text { et al, 1996 (87, 89); } \\
\text { Waldenstrom et al, } \\
\text { 1998 (88); Wiktorin et } \\
\text { al, } 1999 \text { (90); Torgén } \\
\text { et al, 1999 (91); Morti- } \\
\text { mer et al, } 1998 \text { (92) }\end{array}$} & \multirow[t]{3}{*}{ CC } & \multirow[t]{3}{*}{78} & $\begin{array}{l}\text { Persons } 20-59 \\
\text { years of age (ca- }\end{array}$ & \multirow{3}{*}{$\begin{array}{l}\text { Seeking treatment } \\
\text { for neck-shoulder } \\
\text { pain }\end{array}$} & \multirow{3}{*}{$\begin{array}{l}\text { Hand above shoulder } \\
>30 \text { minutes per day } \\
\text { High creativity and low routine } \\
\text { High demands in relation to } \\
\text { competence } \\
\text { High psychosocial demands } \\
\text { High quantitative demands } \\
\text { High routine and low creativity } \\
\text { High time pressure } \\
\text { Job strain }\end{array}$} & RR 1.3 & $0.9-2.0$ & RR 0.9 & $0.6-1.4$ & 1.44 \\
\hline & & & $\begin{array}{l}\text { ses: } N=118 \text { men, } \\
N=274 \text { women; } \\
\text { controls: } N=662\end{array}$ & & & $\begin{array}{l}\text { RR } 0.9 \\
\text { RR } 0.8\end{array}$ & $\begin{array}{l}0.7-1.3 \\
0.5-1.1\end{array}$ & $\begin{array}{l}\text { RR } 0.6 \\
\text { RR } 0.9\end{array}$ & $\begin{array}{l}0.4-1.0 \\
0.6-1.5\end{array}$ & $\begin{array}{l}1.50 \\
0.89\end{array}$ \\
\hline & & & $\begin{array}{l}\text { men, } \mathrm{N}=849 \\
\text { women) }\end{array}$ & & & $\begin{array}{l}\text { RR } 1.1 \\
\text { RR } 0.9 \\
\text { RR } 1.1 \\
\text { RR } 1.3 \\
\text { RR } 1.4\end{array}$ & $\begin{array}{l}0.8-1.5 \\
0.5-1.5 \\
0.7-1.5 \\
0.9-1.8 \\
1.1-2.0\end{array}$ & $\begin{array}{l}\text { RR } 0.7 \\
\text { RR } 0.2 \\
\text { RR } 1.2 \\
\text { RR } 0.5 \\
\text { RR } 1.1\end{array}$ & $\begin{array}{l}0.4-1.0 \\
0.1-0.9 \\
0.7-1.8 \\
0.3-1.0 \\
0.7-1.9\end{array}$ & $\begin{array}{l}1.57 \\
4.50 \\
0.92 \\
2.60 \\
1.27\end{array}$ \\
\hline
\end{tabular}


Table 2. Continued.

\begin{tabular}{|c|c|c|c|c|c|c|c|c|c|c|}
\hline \multirow[t]{3}{*}{ Study a } & \multirow{3}{*}{$\begin{array}{l}\text { De- } \\
\text { sign }\end{array}$} & \multirow{3}{*}{$\begin{array}{l}\mathrm{MQ} F \\
(\%)\end{array}$} & \multirow{3}{*}{ Population } & \multirow[t]{3}{*}{ Outcome } & \multirow[t]{3}{*}{ Exposure } & \multicolumn{4}{|c|}{ Association } & \multirow{3}{*}{$\begin{array}{r}\text { Gender } \\
\text { ratio }^{b}\end{array}$} \\
\hline & & & & & & \multicolumn{2}{|c|}{ Female } & \multicolumn{2}{|c|}{ Male } & \\
\hline & & & & & & $\begin{array}{l}\text { OR, RR } \\
\text { or PR }\end{array}$ & $95 \% \mathrm{Cl}$ & $\begin{array}{l}\text { OR, RR } \\
\text { or PR }\end{array}$ & $95 \% \mathrm{Cl}$ & \\
\hline & & & & & Decision latitude & RR 1.2 & $0.9-1.6$ & RR 1.3 & $0.8-1.9$ & 0.92 \\
\hline & & & & & $\begin{array}{l}\text { Demands in relation to } \\
\text { competence (low) }\end{array}$ & RR 1.0 & $0.7-1.4$ & RR 1.5 & $1.0-2.4$ & 0.67 \\
\hline & & & & & $\begin{array}{l}\text { Participation \& demands in } \\
\text { planning (low) }\end{array}$ & RR 1.2 & $0.7-2.1$ & RR 0.9 & $0.4-2.2$ & 1.33 \\
\hline & & & & & $\begin{array}{l}\text { Manual materials handling } \\
(>50 \mathrm{~N}>60 \text { minutes per day) }\end{array}$ & RR 0.8 & $0.4-1.5$ & RR 1.2 & $0.7-2.0$ & 0.67 \\
\hline & & & & & Poor general support at work & RR 1.2 & $0.9-1.6$ & $\mathrm{RR} 1.3$ & $0.9-1.9$ & 0.92 \\
\hline & & & & & Repetitive movements & RR 1.6 & $1.2-2.2$ & RR 1.2 & $0.8-1.8$ & 1.33 \\
\hline & & & & & $\begin{array}{l}\text { Vibrating tools }>30 \text { minutes/ } \\
\text { day }\end{array}$ & RR 0.8 & $0.4-2.0$ & RR 1.6 & $1.0-2.3$ & 0.50 \\
\hline \multirow{2}{*}{$\begin{array}{l}\text { Mäkelä et al, } 1991 \\
\text { (64); Mäkelä et al, } \\
1999 \text { (93) }\end{array}$} & \multirow[t]{2}{*}{ CS } & \multirow[t]{2}{*}{71} & \multirow{2}{*}{$\begin{array}{l}\text { Persons from the } \\
\text { general popula- } \\
\text { tion }(\mathrm{N}=7217)\end{array}$} & \multirow{2}{*}{$\begin{array}{l}\text { Chronic neck } \\
\text { syndrome }\end{array}$} & Mental stress index & RR 1.78 & $0.48-2.13$ & RR 1.63 & $1.29-2.07$ & 1.09 \\
\hline & & & & & $\begin{array}{l}\text { Physical work index } \\
\text { (high versus other) }\end{array}$ & RR 1.90 & $1.62-2.21$ & RR 1.95 & $1.58-2.39$ & 0.97 \\
\hline \multirow{10}{*}{$\begin{array}{l}\text { Jensen et al, } 2002 \\
(65,99)\end{array}$} & \multirow[t]{10}{*}{ CS } & \multirow{10}{*}{50} & \multirow{10}{*}{$\begin{array}{l}\text { Workers using a } \\
\text { computer at work } \\
\text { ( } \mathrm{N}=7125 \text { men, } \\
\mathrm{N}=821 \text { women) }\end{array}$} & \multirow{5}{*}{$\begin{array}{l}\text { Musculoskeletal } \\
\text { symptoms in the } \\
\text { neck in the past } \\
\text { year }\end{array}$} & Repetitive movements & OR 1.26 & & OR 1.27 & & 0.99 \\
\hline & & & & & $\begin{array}{l}\text { Repetitive movements } \\
\text { and tasks }\end{array}$ & OR 1.59 & & OR 1.86 & & 0.85 \\
\hline & & & & & $\begin{array}{l}\text { Quantitative demands and } \\
\text { development possibilities } \\
\text { (low-low) }\end{array}$ & OR 1.37 & & OR 1.24 & & 1.10 \\
\hline & & & & & $\begin{array}{l}\text { Quantitative demands and } \\
\text { development possibilities } \\
\text { (high-high) }\end{array}$ & OR 1.28 & & OR 1.17 & & 1.09 \\
\hline & & & & & $\begin{array}{l}\text { Quantitative demands and devel- } \\
\text { opment possibilities (high-low) }\end{array}$ & OR 2.21 & & OR 2.05 & & 1.08 \\
\hline & & & & \multirow{5}{*}{$\begin{array}{l}\text { Musculoskeletal } \\
\text { symptoms in the } \\
\text { shoulder in the } \\
\text { past year }\end{array}$} & Repetitive movements & OR 1.71 & & OR 1.20 & & 1.43 \\
\hline & & & & & Repetitive movements \& tasks & OR 1.78 & & OR 0.76 & & 2.34 \\
\hline & & & & & $\begin{array}{l}\text { Quantitative demands } \\
\text { (medium low) }\end{array}$ & OR 0.94 & & OR 1.39 & & 0.68 \\
\hline & & & & & $\begin{array}{l}\text { Quantitative demands } \\
\text { (medium high) }\end{array}$ & OR 1.27 & & OR 1.31 & & 0.97 \\
\hline & & & & & $\begin{array}{l}\text { Quantitative demands } \\
\text { (high) }\end{array}$ & OR 1.60 & & OR 1.50 & & 1.07 \\
\hline \multirow{7}{*}{$\begin{array}{l}\text { Palmer et al, } 2001 \text { (62); } \\
\text { Palmer et al, } 2000 \text { (75) }\end{array}$} & \multirow{7}{*}{ CS } & 36 & Persons 16-64 & Neck pain during & Hand above shoulder $>1$ hour & PR 1.4 & $1.2-1.6$ & PR 1.3 & $1.1-1.4$ & 1.08 \\
\hline & & & $\begin{array}{l}\text { years of age } \\
(N=9368)\end{array}$ & $\begin{array}{l}\text { previous } \\
12 \text { months }\end{array}$ & $\begin{array}{l}\text { Hand-arm vibratıon } \\
\text { Lift } 10-25 \mathrm{~kg} \text { by hand }\end{array}$ & $\begin{array}{l}\text { PR } 1.2 \\
\text { PR } 1.1\end{array}$ & $\begin{array}{l}1-1.4 \\
1-1.3\end{array}$ & $\begin{array}{l}\text { PR } 1.0 \\
\text { PR } 1.0\end{array}$ & $\begin{array}{l}0.9-1.1 \\
0.9-1.1\end{array}$ & $\begin{array}{l}1.20 \\
1.10\end{array}$ \\
\hline & & & & & Lift $>25 \mathrm{~kg}$ by hand & PR 1.1 & $0.9-1.3$ & PR 1.1 & $1.0-1.2$ & 1.00 \\
\hline & & & & Neck pain during & Hand above shoulder $>1$ hour & PR 1.7 & $1.3-2.1$ & PR 1.4 & $1.2-1.6$ & 1.21 \\
\hline & & & & previous 7 days & Hand-arm vibration & PR 0.2 & $0.9-1.5$ & PR 0.9 & $0.8-1.1$ & 0.22 \\
\hline & & & & & Lift $10-25 \mathrm{~kg}$ by hand & PR 1.1 & $0.9-1.3$ & PR 0.9 & $0.7-1.0$ & 1.22 \\
\hline & & & & & Lift $>25 \mathrm{~kg}$ by hand & PR 1.1 & $0.9-1.4$ & PR 1.1 & $1.0-1.3$ & 1.00 \\
\hline Karlqvist, 2002 (66) & CS & 29 & $\begin{array}{l}\text { Workers from } \\
46 \text { worksites }\end{array}$ & $\begin{array}{l}\text { Reported symp- } \\
\text { toms in the neck/ }\end{array}$ & Position of nonkeyboard & PR 1.1 & $1.0-1.3$ & PR 1.3 & $1.0-1.7$ & 0.85 \\
\hline & & & $(\mathrm{N}=489$ men, & shoulders during & Medium \& high job strain & PR 1.3 & $1.1-1.6$ & PR 1.2 & $0.8-1.8$ & 1.08 \\
\hline & & & $\mathrm{N}=785$ women) & $\begin{array}{l}\text { the previous } 3 \\
\text { months }\end{array}$ & & PR 1.1 & $1.0-1.2$ & PR 1.4 & $1.1-1.8$ & 0.79 \\
\hline & & & & & $\begin{array}{l}\text { Probability of meeting time } \\
\text { limits \& quality demands } \\
\text { (less aood-low versus hiah) }\end{array}$ & PR 1.1 & $1.0-1.2$ & PR 1.1 & $0.8-1.4$ & 1.00 \\
\hline & & & & & & PR 1.1 & $0.9-1.2$ & PR 0.9 & $0.7-1.2$ & 1.22 \\
\hline & & & & & $\begin{array}{l}\text { Supervisory social support } \\
\text { (medium-low versus high) }\end{array}$ & PR 1.0 & $0.9-1.2$ & PR 1.1 & $0.8-1.4$ & 0.91 \\
\hline & & & & $\begin{array}{l}\text { Reported symp- } \\
\text { toms in the }\end{array}$ & $\begin{array}{l}\text { Position of nonkeyboard } \\
\text { input device (nonoptimal) }\end{array}$ & PR 1.0 & $0.80-1.20$ & PR 1.2 & $0.8-1.9$ & 0.83 \\
\hline & & & & shoulder joint or & Medium \& high job strain & PR 1.5 & $1.0-2.3$ & PR 0.9 & $0.6-1.5$ & 1.67 \\
\hline & & & & $\begin{array}{l}\text { upper arm during } \\
\text { the previous }\end{array}$ & $\begin{array}{l}\text { Demands not in relation to } \\
\text { competence }\end{array}$ & PR 0.9 & $0.7-1.1$ & PR 0.8 & $0.5-1.2$ & 1.13 \\
\hline & & & & 3 months & $\begin{array}{l}\text { Probability of meeting time } \\
\text { limits \& quality demands } \\
\text { (less good-low versus high) }\end{array}$ & PR 1.3 & $1.1-1.6$ & PR 0.6 & $0.4-1.0$ & 2.17 \\
\hline & & & & & $\begin{array}{l}\text { Social support } \\
\text { (medium-low versus high) }\end{array}$ & PR 1.1 & $0.9-1.3$ & PR 1.1 & $0.7-1.6$ & 1.00 \\
\hline & & & & & $\begin{array}{l}\text { Supervisory social support } \\
\text { (medium-low versus high) }\end{array}$ & PR 1.3 & $1.0-1.7$ & PR 1.0 & $0.7-1.6$ & 1.30 \\
\hline
\end{tabular}


Table 2. Continued.

\begin{tabular}{|c|c|c|c|c|c|c|c|c|c|c|}
\hline \multirow[t]{3}{*}{ Study a } & \multirow{3}{*}{$\begin{array}{l}\text { De- } \\
\text { sign }\end{array}$} & \multirow{3}{*}{$\begin{array}{l}\text { MQ P } \\
(\%)\end{array}$} & \multirow{3}{*}{ Population } & \multirow[t]{3}{*}{ Outcome } & \multirow[t]{3}{*}{ Exposure } & \multicolumn{4}{|c|}{ Association } & \multirow{3}{*}{$\begin{array}{c}\text { Gender } \\
\text { ratio }^{b}\end{array}$} \\
\hline & & & & & & \multicolumn{2}{|c|}{ Female } & \multicolumn{2}{|c|}{ Male } & \\
\hline & & & & & & $\begin{array}{l}\text { OR, RR } \\
\text { or PR }\end{array}$ & $95 \% \mathrm{Cl}$ & $\begin{array}{l}\text { OR, RR } \\
\text { or PR }\end{array}$ & $95 \% \mathrm{Cl}$ & \\
\hline Pope et al, 1997 (63) & CS & 29 & $\begin{array}{l}\text { Persons from a } \\
\text { general practice } \\
\text { (cases: } N=16 \text { men, } \\
N=23 \text { women; con- } \\
\text { trols: } N=79 \text { men, } \\
N=100 \text { women }\end{array}$ & Shoulder pain & $\begin{array}{l}\text { Carrying on one shoulder } \\
\text { Lifting or carrying }>25 \text { lbs } \\
\text { Stretching to reach below knee } \\
\text { Using arms in repetitive way } \\
\text { Using vibrating machinery } \\
\text { Using wrist in repetitive way }\end{array}$ & $\begin{array}{l}\text { RR } 1.1 \\
\text { RR } 0.8 \\
\text { RR } 1.4 \\
\text { RR } 0.9 \\
\text { RR } 0.8 \\
\text { RR } 2.0\end{array}$ & $\begin{array}{l}0.1-8.1 \\
0.3-2.2 \\
0.6-3.3 \\
0.4-2.1 \\
0.2-2.7 \\
0.9-4.6\end{array}$ & $\begin{array}{l}\text { RR } 5.5 \\
\text { RR } 1.2 \\
\text { RR } 2.0 \\
\text { RR } 1.7 \\
\text { RR } 1.1 \\
\text { RR } 2.0\end{array}$ & $\begin{array}{l}1.8-17.4 \\
0.1-3.5 \\
0.7-5.7 \\
0.6-4.8 \\
0.4-3.6 \\
0.7-5.9\end{array}$ & $\begin{array}{l}0.20 \\
0.67 \\
0.70 \\
0.53 \\
0.73 \\
1.00\end{array}$ \\
\hline
\end{tabular}

${ }^{a}$ For references see the general reference list of the review.

${ }^{b}$ Ratio of the risk of women to the risk of men (female/male).

c $1 \mathrm{lbs}=0.4536 \mathrm{~kg}$.

Table 3. Description of the studies on hand-wrist complaints. (CC = case-control, $\mathrm{CH}=$ cohort, $\mathrm{CS}=$ cross-sectional, $\mathrm{OR}=0 \mathrm{dds}$ ratio, $\mathrm{PR}$ $=$ prevalence ratio, $\mathrm{RR}=$ relative risk, $95 \% \mathrm{Cl}=95 \%$ confidence interval)

\begin{tabular}{|c|c|c|c|c|c|c|c|c|c|c|}
\hline \multirow[t]{3}{*}{ Study a } & \multirow{3}{*}{$\begin{array}{l}\text { De- } \\
\text { sign }\end{array}$} & \multirow{3}{*}{$\begin{array}{l}\mathrm{MQ} \\
(\%)\end{array}$} & \multirow{3}{*}{ Population } & \multirow[t]{3}{*}{ Outcome } & \multirow[t]{3}{*}{ Exposure } & \multicolumn{4}{|c|}{ Association } & \multirow{3}{*}{$\begin{array}{l}\text { Gender } \\
\text { ratio }^{\mathrm{b}}\end{array}$} \\
\hline & & & & & & \multicolumn{2}{|c|}{ Female } & \multicolumn{2}{|c|}{ Male } & \\
\hline & & & & & & $\begin{array}{l}\text { OR, RR } \\
\text { or PR }\end{array}$ & $95 \% \mathrm{Cl}$ & $\begin{array}{l}\text { OR, RR } \\
\text { or PR }\end{array}$ & $95 \% \mathrm{Cl}$ & \\
\hline \multirow[t]{3}{*}{$\begin{array}{l}\text { Jensen et al, } 2002 \\
(65,99)\end{array}$} & \multirow[t]{3}{*}{ CS } & \multirow[t]{3}{*}{50} & \multirow{3}{*}{$\begin{array}{l}\text { Workers using a } \\
\text { computer at } \\
\text { work }(N=7125 \\
\text { men, } N=821 \\
\text { women) }\end{array}$} & \multirow[t]{3}{*}{$\begin{array}{l}\text { Musculoskeletal } \\
\text { symptoms in } \\
\text { hand-wrist in } \\
\text { past year }\end{array}$} & $\begin{array}{l}\text { Repetitive movements } \\
\text { Repetitive movements \& tasks } \\
\text { Quantitative demands } \\
\text { (medium-low) }\end{array}$ & $\begin{array}{l}\text { OR } 1.35 \\
\text { OR } 1.58 \\
\text { OR } 0.91\end{array}$ & & \multicolumn{2}{|l|}{$\begin{array}{l}\text { OR } 1.59 \\
\text { OR } 1.88 \\
\text { OR } 1.16\end{array}$} & $\begin{array}{l}0.85 \\
0.84 \\
0.78\end{array}$ \\
\hline & & & & & $\begin{array}{l}\text { Quantitative demands } \\
\text { (medium-high) }\end{array}$ & OR 1.02 & & \multicolumn{2}{|l|}{ OR 1.45} & 0.70 \\
\hline & & & & & $\begin{array}{l}\text { Quantitative demands } \\
\text { (high) }\end{array}$ & OR 1.76 & & \multicolumn{2}{|l|}{ OR 1.27} & 1.39 \\
\hline $\begin{array}{l}\text { Tanaka et al, } 1995 \\
\text { (68); Tanaka et al, } \\
2001 \text { (100); Tanaka } \\
\text { et al, } 1997 \text { (101) }\end{array}$ & CS & 36 & $\begin{array}{l}\text { Workers from a } \\
\text { household } \\
\text { survey } \\
(\mathrm{N}=15427 \text { men, } \\
N=14627 \\
\text { women) }\end{array}$ & $\begin{array}{l}\text { Carpal tunnel } \\
\text { syndrome in } \\
\text { last } 12 \text { months }\end{array}$ & $\begin{array}{l}\text { Bending-twisting } \\
\text { Vibration }\end{array}$ & $\begin{array}{l}\text { RR } 2.91 \\
\text { RR } 1.38\end{array}$ & $\begin{array}{l}2.25-3.76 \\
0.96-2.0\end{array}$ & $\begin{array}{l}\text { RR } 3.66 \\
\text { RR } 2.80\end{array}$ & $\begin{array}{l}2.52-5.32 \\
1.08-3.77\end{array}$ & $\begin{array}{l}0.80 \\
0.49\end{array}$ \\
\hline \multirow[t]{7}{*}{$\begin{array}{l}\text { Fransson-Hall et al, } \\
1995(67)\end{array}$} & \multirow[t]{7}{*}{ CS } & \multirow{7}{*}{36} & \multirow{7}{*}{$\begin{array}{l}\text { Workers ran- } \\
\text { domly selected } \\
\text { from assembly } \\
\text { line workers at a } \\
\text { Swedish auto- } \\
\text { mobile factory } \\
\text { (N=521) }\end{array}$} & \multirow{7}{*}{$\begin{array}{l}\text { Pain, ache or dis- } \\
\text { comfort during } \\
\text { last } 7 \text { days in } \\
\text { the elbow, fore- } \\
\text { arm, wrist, hand } \\
\text { or fingers }\end{array}$} & $\begin{array}{l}\text { Wrist extension \& ulnar } \\
\text { deviation }\end{array}$ & PR 1.3 & $0.9-1.9$ & PR 1.6 & $1.1-2.3$ & 0.81 \\
\hline & & & & & $\begin{array}{l}\text { Wrist extension \& radial } \\
\text { deviation }\end{array}$ & PR 1.2 & $0.8-1.8$ & PR 1.7 & $1.2-2.4$ & 0.71 \\
\hline & & & & & $\begin{array}{l}\text { Wrist flexion \& ulnar } \\
\text { deviation }\end{array}$ & PR 1.4 & $1.0-2.0$ & PR 1.5 & $1.1-2.2$ & 0.93 \\
\hline & & & & & $\begin{array}{l}\text { Wrist flexion \& radial } \\
\text { deviation }\end{array}$ & PR 1.4 & $1.0-2.0$ & PR 1.5 & $1.1-2.2$ & 0.93 \\
\hline & & & & & $\begin{array}{l}\text { Wrist ulnar deviation, } \\
\text { repetitive movements \& } \\
\text { precision movements }\end{array}$ & PR 1.7 & $1.2-2.4$ & PR 1.5 & $0.9-2.3$ & 1.13 \\
\hline & & & & & $\begin{array}{l}\text { Wrist radial deviation, } \\
\text { repetitive movements \& } \\
\text { precision movements }\end{array}$ & PR 1.8 & $1.3-2.5$ & PR 1.4 & $0.8-2.2$ & 1.29 \\
\hline & & & & & $\begin{array}{l}\text { Wrist ulnar-radial deviation, } \\
\text { extension-flexion \& } \\
\text { repetitive movements \& } \\
\text { precision movements }\end{array}$ & PR 1.8 & $1.2-2.6$ & PR 1.6 & $1.0-2.6$ & 1.13 \\
\hline \multirow[t]{4}{*}{ Karlqvist, 2002 (66) } & \multirow[t]{4}{*}{ CS } & \multirow{4}{*}{$\begin{array}{rl}29 & \mathrm{E} \\
4 \\
\\
1\end{array}$} & \multirow{4}{*}{$\begin{array}{l}\text { Employees from } \\
46 \text { worksites } \\
\text { ( } N=489 \text { men, } \\
N=785 \text { women) }\end{array}$} & \multirow{4}{*}{$\begin{array}{l}\text { Reported symp- } \\
\text { toms in the } \\
\text { elbow, forearm, } \\
\text { or hands during } \\
\text { previous } \\
3 \text { months }\end{array}$} & $\begin{array}{l}\text { Position of nonkeyboard input } \\
\text { device (nonoptimal) }\end{array}$ & PR 1.1 & $0.9-1.4$ & PR 1.2 & $0.8-1.7$ & 0.92 \\
\hline & & & & & $\begin{array}{l}\text { Medium \& high job strain } \\
\text { Demands not in relation to } \\
\text { competence }\end{array}$ & $\begin{array}{l}\text { PR } 1.7 \\
\text { PR } 1.1\end{array}$ & $\begin{array}{l}1.1-2.6 \\
0.9-1.3\end{array}$ & $\begin{array}{l}\text { PR } 1.2 \\
\text { PR } 1.4\end{array}$ & $\begin{array}{l}0.7-1.9 \\
1.0-1.9\end{array}$ & $\begin{array}{l}1.42 \\
0.79\end{array}$ \\
\hline & & & & & $\begin{array}{l}\text { Less good-low probability of } \\
\text { meeting time limits \& quality } \\
\text { demands }\end{array}$ & PR 1.1 & $0.9-1.3$ & PR 0.9 & $0.6-1.3$ & 1.22 \\
\hline & & & & & $\begin{array}{l}\text { Medium-low social support } \\
\text { Medium-low supervisory } \\
\text { social support }\end{array}$ & $\begin{array}{l}\text { PR } 1.1 \\
\text { PR } 1.1\end{array}$ & $\begin{array}{l}0.9-1.3 \\
0.9-1.3\end{array}$ & $\begin{array}{l}\text { PR } 1.3 \\
\text { PR } 1.2\end{array}$ & $\begin{array}{l}0.8-1.9 \\
0.8-1.8\end{array}$ & $\begin{array}{l}0.85 \\
0.92\end{array}$ \\
\hline
\end{tabular}

${ }^{a}$ For references see the general reference list of the review.

${ }^{\mathrm{b}}$ Ratio of the risk of women to the risk of men (female/male). 
Table 4. Description of the studies on lower-extremity complaints. ( $\mathrm{CC}=$ case-control, $\mathrm{CH}=$ cohort, $\mathrm{CS}=$ cross-sectional, $\mathrm{OR}=0 \mathrm{dds}$ ratio, $\mathrm{PR}=$ prevalence ratio, $95 \% \mathrm{Cl}=95 \%$ confidence interval)

\begin{tabular}{|c|c|c|c|c|c|c|c|c|c|c|}
\hline \multirow[t]{3}{*}{ Study a } & \multirow{3}{*}{$\begin{array}{l}\text { De- } \\
\text { sign }\end{array}$} & \multirow{3}{*}{$\begin{array}{l}M Q P \\
(\%)\end{array}$} & \multirow{3}{*}{ Population } & \multirow[t]{3}{*}{ Outcome } & \multirow[t]{3}{*}{ Exposure } & \multicolumn{4}{|c|}{ Association } & \multirow{3}{*}{$\begin{array}{l}\text { Gender } \\
\text { ratio }^{\mathrm{b}}\end{array}$} \\
\hline & & & & & & \multicolumn{2}{|c|}{ Female } & \multicolumn{2}{|c|}{ Male } & \\
\hline & & & & & & $\begin{array}{l}\mathrm{OR}, \mathrm{RR} \\
\text { or PR }\end{array}$ & $95 \% \mathrm{Cl}$ & $\begin{array}{l}\text { OR, RR } \\
\text { or PR }\end{array}$ & $95 \% \mathrm{Cl}$ & \\
\hline \multirow[t]{7}{*}{$\begin{array}{l}\text { Coggon et al, } \\
2000(69)\end{array}$} & \multirow[t]{7}{*}{$\mathrm{CC}$} & \multirow[t]{7}{*}{44} & \multirow{7}{*}{$\begin{array}{l}\text { Persons living in } \\
3 \text { health districts } \\
\text { (cases: } N=675 ; \\
\text { controls } N=667 \text { ) }\end{array}$} & \multirow{7}{*}{$\begin{array}{l}\text { On waiting list for } \\
\text { knee surgery due } \\
\text { to osteoarthritis }\end{array}$} & $\begin{array}{l}\text { Climbing ladder or stairs } \\
>30 \text { times/day }\end{array}$ & 0.7 & $0.3-1.6$ & 2.3 & $1.3-4.0$ & 0.30 \\
\hline & & & & & & 1.8 & $1.0-3.2$ & 2.0 & $1.1-3.5$ & 0.90 \\
\hline & & & & & $\begin{array}{l}\text { Kneeling or squatting } \\
>1 \text { hour/day }\end{array}$ & 2.1 & $1.2-3.6$ & 2.0 & $1.1-3.6$ & 1.05 \\
\hline & & & & & Kneeling $>2$ hours/day & 2.0 & $1.1-3.5$ & 1.7 & $1.0-3.0$ & 1.18 \\
\hline & & & & & Squatting $>1$ hour/day & 2.8 & $1.1-7.2$ & 2.2 & $1.0-4.9$ & 1.27 \\
\hline & & & & & Standing or walk $>2$ hours/day & 0.5 & $0.8-2.9$ & 4.1 & $0.3-65.5$ & 0.12 \\
\hline & & & & & Walking $>2$ miles/day ${ }^{c}$ & 2.1 & $1.4-3.2$ & 1.7 & $0.8-3.6$ & 1.24 \\
\hline \multirow[t]{7}{*}{$\begin{array}{l}\text { Manninen et al, } \\
2002 \text { (72) }\end{array}$} & \multirow[t]{7}{*}{$\mathrm{CC}$} & \multirow{7}{*}{44} & \multirow{7}{*}{$\begin{array}{l}\text { Persons } 55-75 \\
\text { years of age } \\
\text { ( } N=194 \text { men, } \\
N=640 \text { women) }\end{array}$} & \multirow{7}{*}{$\begin{array}{l}\text { Knee surgery due } \\
\text { to primary osteo- } \\
\text { arthritis }\end{array}$} & $\begin{array}{l}\text { Heavy physical workload } \\
\text { (medium versus low) }\end{array}$ & 1.60 & $0.83-3.06$ & 2.23 & $0.64-7.72$ & 0.72 \\
\hline & & & & & $\begin{array}{l}\text { Heavy physical workload } \\
\text { (high versus low) }\end{array}$ & 2.03 & $1.03-3.99$ & 1.53 & $0.42-5.56$ & 1.33 \\
\hline & & & & & $\begin{array}{l}\text { Kneeling or squatting }<2 \text { hours } \\
\text { Kneeling or squatting }>2 \text { hours }\end{array}$ & $\begin{array}{l}0.97 \\
1.81\end{array}$ & $\begin{array}{l}0.59-1.59 \\
1.11-2.95\end{array}$ & $\begin{array}{l}0.58 \\
1.68\end{array}$ & $\begin{array}{l}0.21-1.64 \\
0.66-4.28\end{array}$ & $\begin{array}{l}1.67 \\
1.08\end{array}$ \\
\hline & & & & & $\begin{array}{l}\text { Climbing } \\
\text { (medium versus low level) }\end{array}$ & 1.08 & $0.71-1.63$ & 3.06 & $1.25-7.46$ & 0.35 \\
\hline & & & & & $\begin{array}{l}\text { Climbing } \\
\text { (high versus low level) }\end{array}$ & 1.50 & $0.81-2.77$ & 2.79 & $0.96-8.16$ & 0.54 \\
\hline & & & & & $\begin{array}{l}\text { Walking } \\
\text { (medium versus low level) }\end{array}$ & 0.89 & $0.56-1.42$ & 2.07 & $0.73-5.89$ & 0.43 \\
\hline & & & & & $\begin{array}{l}\text { Walking } \\
\text { (high versus low level) }\end{array}$ & 1.06 & $0.64-1.76$ & 1.47 & $0.55-3.89$ & 0.72 \\
\hline \multirow[t]{12}{*}{$\begin{array}{l}\text { Coggon et al, } \\
1998(70)\end{array}$} & \multirow[t]{12}{*}{ CC } & \multirow{12}{*}{$\begin{array}{rl}39 & P \\
2 \\
\\
1 \\
n\end{array}$} & \multirow{12}{*}{$\begin{array}{l}\text { Persons living in } \\
2 \text { health districts } \\
\text { ( } N=420 \text { men, } \\
N=802 \text { women) }\end{array}$} & \multirow{12}{*}{$\begin{array}{l}\text { On waiting list } \\
\text { due to hip osteo- } \\
\text { arthritis }\end{array}$} & $\begin{array}{l}\text { Kneeling }>1 \text { hour } \\
(0.1-9.9 \text { years })^{d}\end{array}$ & 0.9 & $0.6-1.4$ & 0.8 & $0.4-1.4$ & 1.13 \\
\hline & & & & & & 0.7 & $0.4-1.3$ & 2.0 & $0.8-4.7$ & 0.35 \\
\hline & & & & & $\begin{array}{l}\text { Kneeling }>1 \text { hour } \\
(>20 \text { years })^{d}\end{array}$ & 1.2 & $0.5-3.0$ & 1.0 & $0.6-1.7$ & 1.20 \\
\hline & & & & & $\begin{array}{l}\text { Squatting }>1 \text { hour } \\
(0.1-9.9 \text { years })^{d}\end{array}$ & 1.1 & $0.6-1.9$ & 0.9 & $0.5-1.6$ & 1.22 \\
\hline & & & & & $\begin{array}{l}\text { Squatting }>1 \text { hour } \\
(10-19.9 \text { years })^{d}\end{array}$ & 1.5 & $0.6-3.4$ & 1.4 & $0.5-3.6$ & 1.07 \\
\hline & & & & & $\begin{array}{l}\text { Squatting }>1 \text { hour } \\
(>20 \text { years })^{d}\end{array}$ & 0.7 & $0.3-1.8$ & 0.9 & $0.5-1.6$ & 0.78 \\
\hline & & & & & $\begin{array}{l}\text { Walking }>2 \text { miles }{ }^{c} \\
(0.1-9.9 \text { years })^{d}\end{array}$ & 1.5 & $1.0-2.3$ & 0.8 & $0.4-1.9$ & 1.88 \\
\hline & & & & & $\begin{array}{l}\text { Walking >2 miles }{ }^{c} \\
(10-19.9 \text { years })^{d}\end{array}$ & 1.5 & $1.0-2.0$ & 1.1 & $0.4-2.5$ & 1.36 \\
\hline & & & & & $\begin{array}{l}\text { Walking }>2 \text { miles }{ }^{c} \\
(>20 \text { years })^{d}\end{array}$ & 1.3 & $0.8-2.0$ & 1.2 & $0.6-2.5$ & 1.08 \\
\hline & & & & & $\begin{array}{l}\text { Climbing }>30 \text { flights of stairs } \\
(0.1-9.9 \text { years })^{\mathrm{d}}\end{array}$ & 1.4 & $0.8-2.0$ & 1.3 & $0.7-2.5$ & 1.08 \\
\hline & & & & & $\begin{array}{l}\text { Climbing > } 30 \text { flights of stairs } \\
(10-19.9 \text { years })^{d}\end{array}$ & 1.3 & $0.4-4.0$ & 2.3 & $1.1-4.9$ & 0.57 \\
\hline & & & & & $\begin{array}{l}\text { Climbing }>30 \text { flights of stairs } \\
(>20 \text { years })^{d}\end{array}$ & 2.3 & $0.8-6.3$ & 1.8 & $0.9-3.4$ & 1.28 \\
\hline \multirow{7}{*}{$\begin{array}{l}\text { Lau et al, } 2000(71) \text {; } \\
\text { Cooper et al, } 1994 \text { (98) }\end{array}$} & $\mathrm{CC}$ & 39 & Hip (cases e: $N=$ & Osteoarthritis of & Climbing & 2.3 & $0.6-8.1$ & 12.5 & $1.5-104.3$ & 0.18 \\
\hline & & & 30 men, $N=108$ & hip, grade III / IV & Kneeling & 1.3 & $0.7-2.5$ & 3.9 & $1.1-14.2$ & 0.33 \\
\hline & & & women; con- & & Squatting $>1$ hour/day & 1.6 & $1.0-2.8$ & 1.3 & $0.5-3.2$ & 1.23 \\
\hline & & & $\begin{array}{l}\text { trols }^{f:} \mathrm{N}=90 \text { men, } \\
\mathrm{N}=324 \text { women) }\end{array}$ & & $\begin{array}{l}\text { Walking } \\
\text { Walking }\end{array}$ & $\begin{array}{l}1.4 \\
0.8\end{array}$ & $\begin{array}{l}0.9-2.3 \\
0.5-1.1\end{array}$ & $\begin{array}{l}3.9 \\
1.0\end{array}$ & $\begin{array}{l}1.3-12.1 \\
0.5-2.1\end{array}$ & $\begin{array}{l}0.36 \\
0.80\end{array}$ \\
\hline & & & Knee (cases e: & Osteoarthritis of & Climbing & 5.1 & $2.5-10.2$ & 2.5 & $1.0-6.4$ & 2.04 \\
\hline & & & $\mathrm{N}=166$ men, & knee, grade III/ IV & Kneeling & 0.9 & $0.6-1.3$ & 1.4 & & 0.64 \\
\hline & & & $\begin{array}{l}\mathrm{N}=492 \text { women; } \\
\text { controls }{ }^{\mathrm{f}} \text { : } \\
\mathrm{N}=166 \text { men, } \\
\mathrm{N}=492 \text { women) }\end{array}$ & & Squatting $>1$ hour/day & 1.1 & $0.8-1.5$ & 1.2 & $0.7-2.0$ & 0.92 \\
\hline
\end{tabular}

a For references see the general reference list of the review.

${ }^{b}$ Ratio of the risk of women to the risk of men (female/male).

c 1 mile = approximately $1.6 \mathrm{~km}$.

d Exposure up to 10 years before the study.

e Patients with osteoarthritis of hip and knee.

${ }^{\dagger}$ Consecutive patients of 8 general practices. 